\title{
Optimization of the Catalytic Asymmetric Addition of Nitroalkanes to Cyclic Enones with trans-4,5-Methano- L-Proline
}

Stephen Hanessian, Zhihui Shao, Jayakumar S. Warrier

Department of Chemistry, Université de Montréal, C.P. 6128, Succ. Centre-ville, Montréal, QC, H3C 3J7

(43 pages) 


\section{Supporting Information}

\section{General Procedure}

\section{3-(2-Nitropropane -2-yl) cyclohexanone}

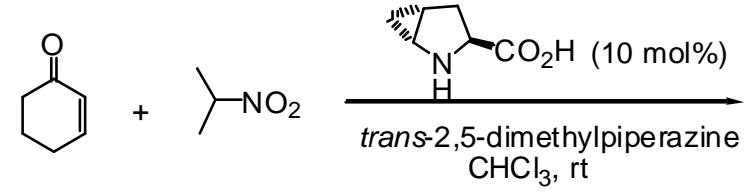<smiles>CC(C)(C1CCCC(=O)C1)[N+](=O)[O-]</smiles>

A mixture of 2-cyclohexen-1-one (50 mg, $0.52 \mathrm{mmol}), 2$-nitropropane (100 $\mu \mathrm{L}, 1.1$ mmol), 2,5-dimethylpiperazine $(60 \mathrm{mg}, 0.53 \mathrm{mmol})$ and a catalytic amount of transmethanoproline $(10 \mathrm{~mol} \%)$ were stirred in the reagent chloroform $(4 \mathrm{~mL})$ for $140 \mathrm{~h}$ at $\mathrm{rt}$. The reaction mixture was diluted with $\mathrm{CH}_{2} \mathrm{Cl}_{2}$ and washed with $1 \mathrm{M} \mathrm{HCl}$. The organic phase was dried with $\mathrm{Na}_{2} \mathrm{SO}_{4}$, filtered, concentrated and chromatographed on a silica column to obtain a colorless solid $(88 \mathrm{mg}, 92 \%)$. mp 102-104 ${ }^{\circ} \mathrm{C} ;[\alpha]_{\mathrm{D}}+24.8(c 1.0$, $\mathrm{CHCl}_{3}, 99 \%$ ee $) ;{ }^{1} \mathrm{H}-\mathrm{NMR}\left(400 \mathrm{MHz}, \mathrm{CDCl}_{3}\right) \delta$ 2.45-2.30 (m, 3H), 2.28-2.17 (m, 1H), 2.17-2.05 (m, 2H), 1.83-1.74 (m, 1H), 1.74-1.48 (m, 1H), 1.55 (s, 3H), $1.54(\mathrm{~s}, 3 \mathrm{H}), 1.48$ $1.33(\mathrm{~m}, 1 \mathrm{H}) ;{ }^{13} \mathrm{C}-\mathrm{NMR}\left(100 \mathrm{MHz}, \mathrm{CDCl}_{3}\right) \delta 208.9,90.6,46.5,42.6,40.7,25.9,24.3$, 23.5, 22.4; HRMS (FAB) calcd. for $\mathrm{C}_{9} \mathrm{H}_{16} \mathrm{NO}_{3}(\mathrm{M}+1)^{+}$186.1130, found 186.1138. Under argon atmosphere, a mixture of 3-(2-nitropropane-2-yl)-cyclohexanone (50 mg, 0.27 mmol), (2R,3R)-2,3-butane diol $(46.6 \mu \mathrm{L}, 0.51 \mathrm{mmol})$ and a catalytic amount of $p$ toluensulfonic acid in dry benzene $(10 \mathrm{~mL})$ were heated for $1 \mathrm{~h}$. The reaction was cooled to $\mathrm{rt}$, added ethyl acetate $(15 \mathrm{~mL})$ and washed with saturated $\mathrm{NaHCO}_{3}$. The organic phase was dried with $\mathrm{Na}_{2} \mathrm{SO}_{4}$, filtered and concentrated to obtain the corresponding ketal as a colorless oil (69 mg, quant.). The enantiomeric excess was determined by ${ }^{13} \mathrm{C}-\mathrm{NMR}$ (100 $\mathrm{MHz}, \mathrm{CDCl}_{3}$ ) of the ketal, and only one isomer was observed. 
3-(5-Nitropentene) cyclohexanone, 9 and 10

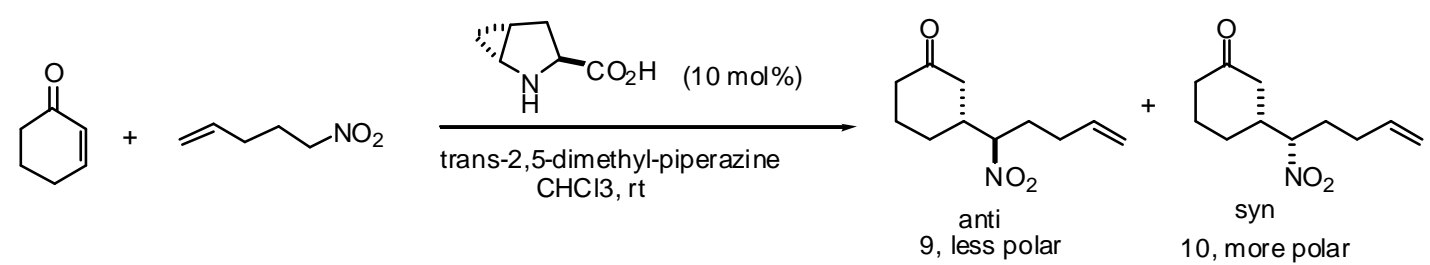

A mixture of 2-cyc lohexen-1-one (50 mg, $0.52 \mathrm{mmol}), 5$-nitro-pent-1-ene (126.5 mg, 1.1 mmol), 2,5-dimethylpiperazine $(60 \mathrm{mg}, 0.53 \mathrm{mmol})$ and a catalytic amount of transmethanoproline $(10 \mathrm{~mol} \%)$ were stirred in the reagent chloroform $(4 \mathrm{~mL})$ for $144 \mathrm{~h}$ at $\mathrm{rt}$. The reaction mixture was diluted with $\mathrm{CH}_{2} \mathrm{Cl}_{2}$ and washed with $1 \mathrm{M} \mathrm{HCl}$. The organic phase was dried with $\mathrm{Na}_{2} \mathrm{SO}_{4}$, filtered, concentrated and chromatographed on a silica column to obtain a colorless oil (103 mg, 94\%), and the less polar/the more polar is 1/1.5.

The less polar (anti): $[\alpha]_{\mathrm{D}}+19.1$ (c $1.4, \mathrm{CHCl}_{3}, 87 \%$ ee $) ;{ }^{1} \mathrm{H}-\mathrm{NMR}\left(400 \mathrm{MHz}, \mathrm{CDCl}_{3}\right) \delta$ 5.77-5.67 (m, 1H), 5.08-5.03 (m, 2H), 4.42-4.36 (m, 1H), 2.52-2.46 (m, 1H), 2.45-2.38 (m, 1H), 2.34-2.22 (m, 2H), 2.15-1.98 (m, 5H), 1.88-1.75 (m, 2H), 1.70-1.58 (m, 1H), 1.53-1.43 (m, 1H); ${ }^{13} \mathrm{C}$ NMR (100 MHz, $\left.\mathrm{CDCl}_{3}\right)$ 208.234, 135.363, 116.737, 91.579, 43.782, 41.551, 40.748, 29.613, 29.583, 27.223, 24.030 ( $\mathbf{\delta} \mathbf{C D C l}_{\mathbf{3}} \mathbf{7 6 . 8 6 7}$ ); HRMS calcd. for $\mathrm{C}_{11} \mathrm{H}_{18} \mathrm{NO}_{3}[\mathrm{M}+1]^{+} 212.1286$, found 212.1294.

The enantiomeric excess was determined by ${ }^{13} \mathrm{C}-\mathrm{NMR}$ of the ketal, observing at $(100$ $\left.\mathrm{MHz}, \mathrm{CDCl}_{3}\right) \delta 36.5 / 35.5$ and 22.1/21.7 when trans-methanoproline was used as catalyst.

The more polar (syn): $[\alpha]_{\mathrm{D}}-10.8\left(c 1.3, \mathrm{CHCl}_{3}, 77 \%\right.$ ee $) ;{ }^{1} \mathrm{H}-\mathrm{NMR}\left(400 \mathrm{MHz}, \mathrm{CDCl}_{3}\right) \delta$ 5.78-5.68 (m, 1H), 5.09-5.04 (m, 2H), 4.47-4.42 (m, 1H), 2.44-2.36 (m, 2H), 2.30-2.19 (m, 3H), 2.18-2.08 (m, 3H), 2.07-1.97 (m, 2H), 1.84-1.76 (m, 1H), 1.71-1.59 (m, 1H), $1.49-1.38(\mathrm{~m}, 1 \mathrm{H}) ;{ }^{13} \mathrm{C}$ NMR $\left(100 \mathrm{MHz}, \mathrm{CDCl}_{3}\right) \delta 208.311,135.386,116.762,91.495$, 43.136, 41.363, 40.707, 29.703, 29.537, 27.577, 24.249 ( $\delta \mathbf{C D C l}_{\mathbf{3}} \mathbf{7 6 . 8 6 7}$ ); HRMS calcd. for $\mathrm{C}_{11} \mathrm{H}_{18} \mathrm{NO}_{3}[\mathrm{M}+1]^{+} 212.1286$, found 212.1291.

The enantiomeric excess was determined by ${ }^{13} \mathrm{C}-\mathrm{NMR}$ of the ketal, observing at $(100$ $\left.\mathrm{MHz}, \mathrm{CDCl}_{3}\right) \delta 36.5 / 35.5$ and 22.4/22.0 when trans-methanoproline was used as catalyst. 


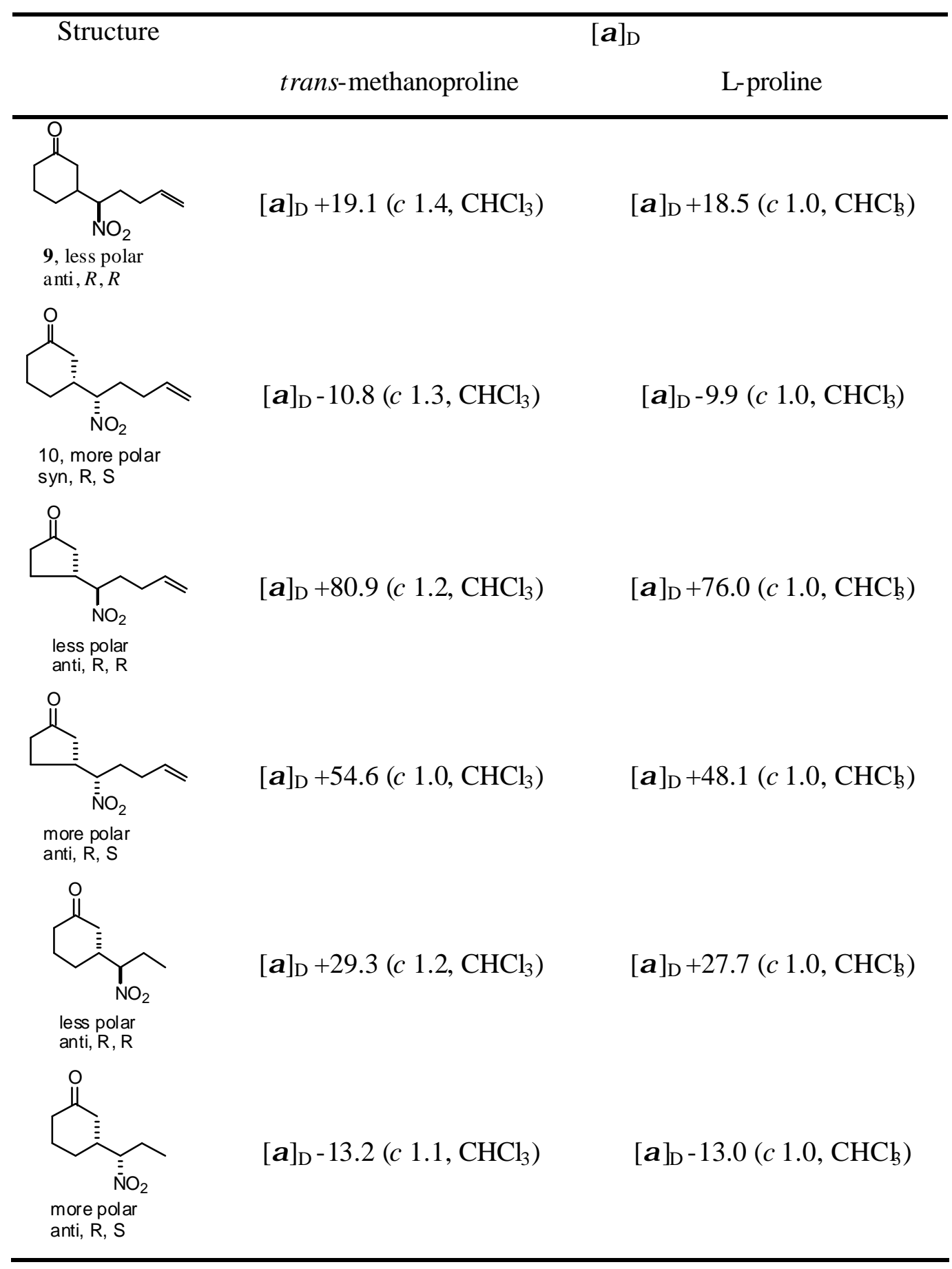




\section{Preparation of $\mathrm{L}$-proline hydroxamic acid:}

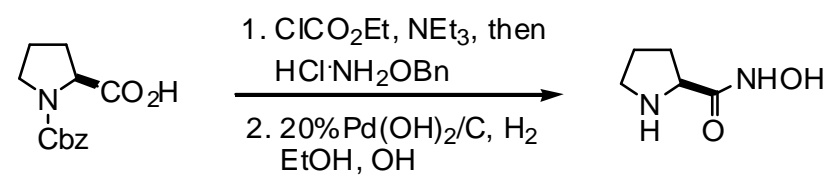

To a solution of Cbz-L-proline $(2.2 \mathrm{~g}, 8.7 \mathrm{mmol})$ in THF (30 mL) was added $\mathrm{NEt}_{3}(2.4$ $\mathrm{mL}, 17.5 \mathrm{mmol}$ ) at $0{ }^{\circ} \mathrm{C}$. The resulting solution was stirred for 15 minutes and $\mathrm{ClCO}_{2} \mathrm{Et}$ $(0.85 \mathrm{~mL}, 8.7 \mathrm{mmol})$ was added slowly at $0{ }^{\circ} \mathrm{C}$. The reaction mixture was stirred for 30 minutes at $0{ }^{\circ} \mathrm{C}$ and $O$-benzylhydroxyamine hydrochloride $(1.7 \mathrm{~g}, 10.4 \mathrm{mmol})$ was added. The resulting solution was stirred over $12 \mathrm{~h}$ and then quenched with a saturated $\mathrm{NH}_{4} \mathrm{Cl}$ solution $(15 \mathrm{~mL})$. The aqueous phase was extracted with DCM $(3 \times 50 \mathrm{~mL})$. The organic phase was washes successively washed with $2 \% \mathrm{HCl}(50 \mathrm{~mL})$, brine $(50 \mathrm{~mL})$, and dried over with $\mathrm{Na}_{2} \mathrm{SO}_{4}$. The solvent was removed by evapo ration to yield a residue which was purified by flash chromatography to give protected hydroxamic acid (2.8 g, 90\%). This was dissolved in $\mathrm{EtOH}(30 \mathrm{~mL})$ and $20 \% \mathrm{Pd}(\mathrm{OH})_{2}$ over activated carbon $(0.1 \mathrm{~g})$ was added. The mixture was stirred under $\mathrm{H}_{2}$ for $30 \mathrm{~min}$. The solution was filtered over a bed of Celite and filtrate was evaporated. The residue was dissolved in water and freezed dry to afford the pure L-proline hydroxamic acid $(1.3 \mathrm{~g}, 99 \%)$ as a white solid. mp $68-69{ }^{\circ} \mathrm{C}$; $[\alpha]_{\mathrm{D}}-61.2\left(c\right.$ 0.5, MeOH); ${ }^{13} \mathrm{C}$ NMR $\left(100 \mathrm{MHz}, \mathrm{DMSO}-d_{6}\right) \delta$ 171.5, 59.4, 47.6, 31.3, 26.6. $\mathrm{m} / \mathrm{z} 131[\mathrm{M}+1]^{+}$.

1. Hanessian, S.; Govindan, S.; Warrier, J. S. Chirality, 2005, 7, 5143

2. Pirrung, M. C. and Chau, J. H. L. J. Org. Chem. 1995, 60, 8084

\section{3-(2-Nitropropa ne-2-yl) cyclohexanone}



A mixture of 2-cyclohexen-1-one $(50 \mu \mathrm{L}, 0.52 \mathrm{mmol}), 2$-nitropropane $(100 \mu \mathrm{L}, 1.1$ $\mathrm{mmol})$, 2,5-dimethylpiperazine (60 $\mathrm{mg}, 0.53 \mathrm{mmol}$ ) and a catalytic amount of L-proline hydroxamic acid $(10 \mathrm{~mol} \%)$ were stirred in the reagent chloroform $(4 \mathrm{~mL})$ for $162 \mathrm{~h}$ at $\mathrm{rt}$. The reaction mixture was diluted with $\mathrm{CH}_{2} \mathrm{Cl}_{2}$ and washed with $3 \%$ aqueous $\mathrm{HCl}$. The 
organic phase was dried with $\mathrm{Na}_{2} \mathrm{SO}_{4}$, filtered, concentrated and chromatographed on a silica column to obtain a colorless solid $(73 \mathrm{mg}, 78 \%)$. $[\alpha]_{\mathrm{D}}+17.1$ (c 1.0, $\mathrm{CHCb}, 75 \%$ $e e)$. The enantiomeric excess was determined by ${ }^{13} \mathrm{C}-\mathrm{NMR}\left(100 \mathrm{MHz}, \mathrm{CDCl}_{3}\right)$ of the ketal with $(2 R, 3 R)$-2,3-butane diol, observing at $\delta 44.1 / 43.6,38.3 / 37.2$ and 36.6/35.5.

\section{Preparation of trans-methanoproline hydroxamic acid:}
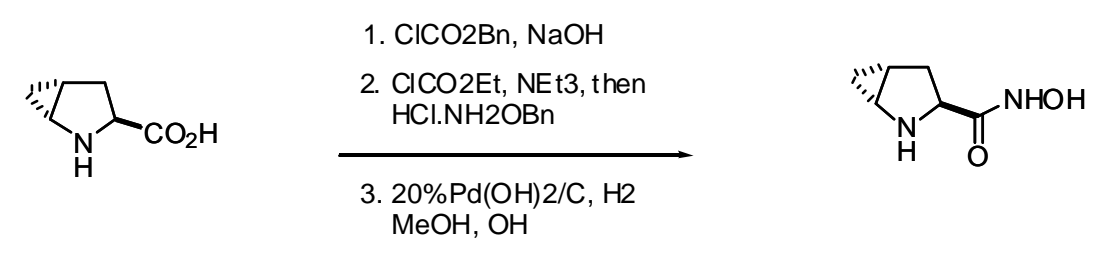

To a $2 \mathrm{M}$ sodium hydroxide aqueous solution $(0.2 \mathrm{~mL})$ cooled with ice-salt bath was added trans-methanoproline $(50 \mathrm{mg}, 0.39 \mathrm{mmol})$. To the resulting solution maintained at $0 \sim-5{ }^{\circ} \mathrm{C}$ was added dropwise benzyl chloroformate $(80 \mathrm{mg}, 0.47 \mathrm{mmol})$ and $4 \mathrm{M}$ sodium hydroxide aqueous solution $(0.14 \mathrm{~mL})$. The reaction mixture was stirred for $1 \mathrm{~h}$ at $0 \sim-5$ ${ }^{\circ} \mathrm{C}$. The aqueous solution was acidified to $\mathrm{pH} 2$ by dropwise addition of $6 \mathrm{M}$ hydrochloric acid and the resulting mixture was saturated with $\mathrm{Na}_{2} \mathrm{SO}_{4}$ and extracted with ethyl acetate $(3 \times 15 \mathrm{~mL})$. The extracts were combined, dried over anhydrous $\mathrm{Na}_{2} \mathrm{SO}_{4}$, and evaporated under reduced pressure to give a oil which was dissolved in THF (2 mL) and $\mathrm{NEt}_{3}$ (77 $\mathrm{mg}, 0.77 \mathrm{mmol}$ ) was added at $0{ }^{\circ} \mathrm{C}$. The resulting solution was stirred for 15 minutes and $\mathrm{ClCO}_{2} \mathrm{Et}(41.6 \mathrm{mg}, 0.38 \mathrm{mmol})$ was slowly added at $0{ }^{\circ} \mathrm{C}$. The reaction mixture was stirred for 30 minutes at $0{ }^{\circ} \mathrm{C}$ and O-benzylhydroxyamine hydrochloride $(73.4 \mathrm{mg}, 0.46$ mmol) was added. The resulting solution was stirred over $10 \mathrm{~h}$ then quenched with saturated $\mathrm{NH}_{4} \mathrm{Cl}$ solution. The aqueous phase was extracted with DCM $(3 \times 15 \mathrm{~mL})$. The organic phase was successively washed with $3 \% \mathrm{HCl}$, brine and dried over with $\mathrm{Na}_{2} \mathrm{SO}_{4}$. The solvent was removed by evaporation to yield a residue which was purified by column chromatography to yield $56 \mathrm{mg}$ protected hydroxamic acid (39\% over two steps). This was dissolved in $\mathrm{MeOH}(2 \mathrm{~mL})$ and $20 \% \mathrm{Pd}(\mathrm{OH})_{2}$ over activated carbon (ca. $5 \mathrm{mg}$ ) was added. The mixture was stirred under $\mathrm{H}_{2}$ for $15 \mathrm{~min}$. The solution was filtered over a bed of Celite and filtrate was evaporated. The residue was dissolved in water and freezed dry to afford the pure trans-methanoproline hydroxamic acid. $[\alpha]_{\mathrm{D}}-39.2(c 0.5, \mathrm{MeOH}) ;{ }^{1} \mathrm{H}$ 
NMR (400 MHz, DMSO- $\left.d_{6}\right) \delta$ 3.18-3.14 (m, 2H), 2.51-2.49 (m, 1H), 2.01-1.97 (m, 1H), 1.75-1.71 (m, 1H), 1.31-1.28 (m, 1H), $0.92(\mathrm{~m}, 1 \mathrm{H}), 0.34-0.29(\mathrm{~m}, 2 \mathrm{H}) ;{ }^{13} \mathrm{C}$ NMR (100 $\mathrm{MHz}, \quad$ DMSO- $\left.d_{6}\right) \quad \delta 171.9,57.9,39.7,35.7,17.3,11.5 ; \mathrm{HRMS}$ calcd. for $\mathrm{C}_{6} \mathrm{H}_{11} \mathrm{~N}_{2} \mathrm{O}_{2}$ $[\mathrm{M}+1]^{+} 143.0815$, found 143.0816 .

\section{3-(2-Nitropropane -2-yl) cyclohexanone}<smiles>CC(C)[N+](=O)[O-]</smiles>
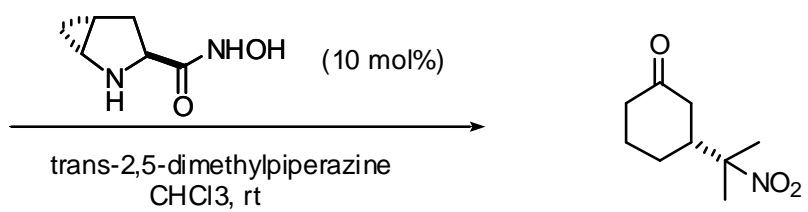

A mixture of 2-cyclohexen-1-one (50 $\mu \mathrm{L}, 0.52 \mathrm{mmol}), 2$-nitropropane (100 $\mu \mathrm{L}, 1.1$ mmol), 2,5-dimethylpiperazine $(60 \mathrm{mg}, 0.53 \mathrm{mmol})$ and a catalytic amount of transmethanoproline hydroxamic acid $(10 \mathrm{~mol} \%)$ were stirred in the reagent chloroform (4 $\mathrm{mL}$ ) for $216 \mathrm{~h}$ at $\mathrm{rt}$. The reaction mixture was diluted with $\mathrm{CH}_{2} \mathrm{Cl}_{2}$ and washed with $3 \%$ aqueous $\mathrm{HCl}$. The organic phase was dried with $\mathrm{Na}_{2} \mathrm{SO}_{4}$, filtered, concentrated and chromatographed on a silica column to obtain a colorless solid $(63 \mathrm{mg}, 65 \%)$. $[\alpha]_{\mathrm{D}}+20.9$ (c $1.0, \mathrm{CHCl}_{3}, 81 \%$ ee). The enantiomeric excess was determined by ${ }^{13} \mathrm{C}-\mathrm{NMR}$ (100 $\mathrm{MHz}, \mathrm{CDC} \xi)$ of the ketal with $(2 R, 3 R)$-2,3-butane diol, observing at $\delta$ 44.1/43.6, $38.3 / 37.2$ and $36.6 / 35.5$.

\section{3-(1-Nitro-propyl)-cyclohexanone}
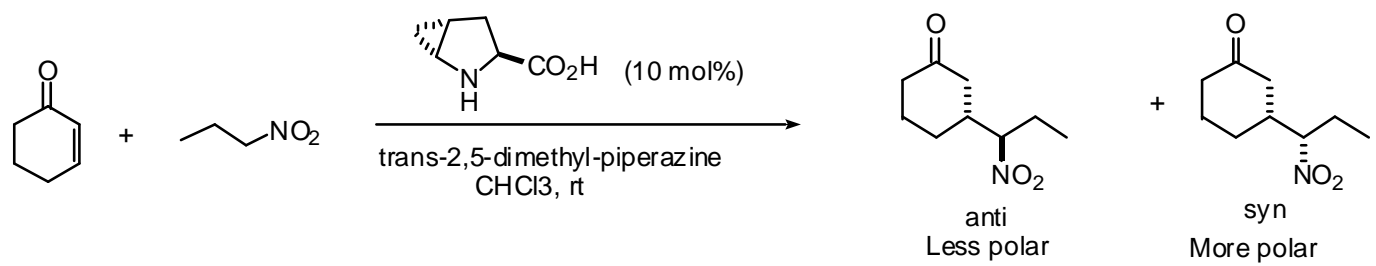

A mixture of 2-cyclohexen-1-one (50 mg, $0.52 \mathrm{mmol})$, 1-nitro-propane (100 $\mu \mathrm{L}, 1.1$ mmol), 2,5-dimethylpiperazine $(60 \mathrm{mg}, 0.53 \mathrm{mmol})$ and a catalytic amount of transmethanoproline (10 mol\%) were stirred in the reagent chloroform $(4 \mathrm{~mL})$ for $144 \mathrm{~h}$ at $\mathrm{rt}$. The reaction mixture was diluted with $\mathrm{CH}_{2} \mathrm{Cl}_{2}$ and washed with $1 \mathrm{M} \mathrm{HCl}$. The organic 
phase was dried with $\mathrm{Na}_{2} \mathrm{SO}_{4}$, filtered, concentrated and chromatographed on a silica column to obtain a colorless oil ( $86 \mathrm{mg}, 89 \%$ ), and the less polar/the more polar is $1 / 2$.

\section{Less polar isomer:}

$[\alpha]_{\mathrm{D}}+29.3\left(\right.$ c $1.2, \mathrm{CHCl}_{3}, 91 \%$ ee); ${ }^{1} \mathrm{H}-\mathrm{NMR}\left(400 \mathrm{MHz}, \mathrm{CDCl}_{3}\right) \delta$ 4.29-4.24 (m, 1H), 2.47-2.45 (m, 1H), 2.44-2.42 (m, 1H), 2.40-2.19 (m, 2H), 2.11-2.03 (m, 2H), 1.99-1.86 $(\mathrm{m}, 1 \mathrm{H}), 1.84-1.75(\mathrm{~m}, 2 \mathrm{H}), 1.67-1.55(\mathrm{~m}, 1 \mathrm{H}), 1.49-1.21(\mathrm{~m}, 1 \mathrm{H}), 0.92(\mathrm{t}, J=7.3 \mathrm{~Hz}$, $3 \mathrm{H}) ;{ }^{13} \mathrm{C}$ NMR $\left(100 \mathrm{MHz}, \mathrm{CDCl}_{3}\right) \delta 206.1,91.6,41.2,38.9,38.3,24.9,21.6,21.5,7.6$; HRMS calcd. for $\mathrm{C}_{9} \mathrm{H}_{16} \mathrm{NO}_{3}[\mathrm{M}+1]^{+} 186.1124$, found 186.1125 .

The enantiomeric excess was determined by ${ }^{13} \mathrm{C}-\mathrm{NMR}$ of the ketal, observing at (100 $\left.\mathrm{MHz}, \mathrm{CDCl}_{3}\right) \delta 36.7 / 35.8,22.4 / 21.9$ when trans-methanoproline was used as catalyst.

\section{More polar isomer:}

$[\alpha]_{\mathrm{D}}-13.2\left(c\right.$ 1.1, $\left.\mathrm{CHCl}_{3}, 74 \% e e\right) ;{ }^{1} \mathrm{H}-\mathrm{NMR}\left(400 \mathrm{MHz}, \mathrm{CDCl}_{3}\right) \delta$ 4.36-4.31 (m, 1H), 2.42-2.37 (m, 2H), 2.30-2.21 (m, 3H), 2.17-2.06 (m, 1H), 2.04-1.94 (m, 2H), 1.87-1.78 $(\mathrm{m}, 1 \mathrm{H}), 1.71-1.59(\mathrm{~m}, 1 \mathrm{H}), 1.47-1.37(\mathrm{~m}, 1 \mathrm{H}), 0.95(\mathrm{t}, J=7.3 \mathrm{~Hz}, 3 \mathrm{H}) ;{ }^{13} \mathrm{C} \mathrm{NMR}(100$ $\left.\mathrm{MHz}, \mathrm{CDCl}_{3}\right) \delta 206.1,91.7,40.8,38.8,38.3,25.1,21.9,21.5,7.8$;

The enantiomeric excess was determined by ${ }^{13} \mathrm{C}-\mathrm{NMR}$ of the ketal, observing at (100 $\left.\mathrm{MHz}, \mathrm{CDCl}_{3}\right) \delta 39.6 / 39.1,36.7 / 35.8$ and 22.6/22.3 when trans-methanoproline was used as catalyst.

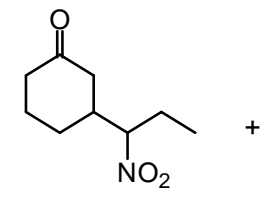

More polar
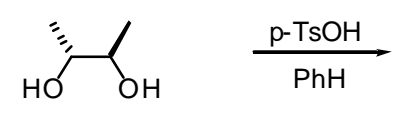

${ }^{13} \mathrm{C}$ NMR (100 MHz, $\left.\mathrm{CDCl}_{3}\right)$ of the minor:



main isomer

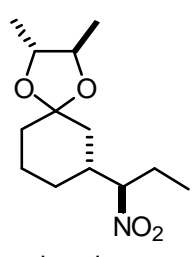

minor isomer

$\delta$ 107.23, 95.05, 78.38, $77.94,39.65,38.67,35.79,27.79,24.21,22.62,17.00,16.91,10.5$

0 . This is in agreement with Prof. Maruoka's ${ }^{13} \mathrm{C}$ NMR $\left(100 \mathrm{MHz}, \mathrm{CDCl}_{3}\right)$ of the syn isomer: $\delta$ 107.2, 95.0, 78.3, 77.8, 39.6, 38.6, 35.8, 27.8, 24.2, 22.6, 17.0, 16.9, 10.5. 


\section{3-(2-Nitropropane -2-yl) cyclohexanone}

$[\alpha]_{\mathrm{D}}+22.8\left(c 1.0, \mathrm{CHCl}_{3}, 89 \% e e\right.$ ) ; The enantiomeric excess was determined by ${ }^{13} \mathrm{C}-$ NMR (100 MHz, $\mathrm{CDCl}_{3}$ ) of the ketal, observing at $\delta 44.1 / 43.6,38.3 / 37.2$ and 36.6/35.5 when L-proline was used as catalyst; $[\alpha]_{\mathrm{D}}+17.4(c) 1.3, \mathrm{CHCl}_{3}, 75 \%$ ee $)$; The enantiomeric excess was determined by ${ }^{13} \mathrm{C}-\mathrm{NMR}\left(100 \mathrm{MHz}, \mathrm{CDCl}_{3}\right)$ of the ketal, observing at $\delta 44.1 / 43.6,38.3 / 37.2$ and $36.6 / 35.5$ when cis-methanoproline was used as catalyst.

\section{3-(1-Nitrocyclopentyl) cyclohexanone}

$[\alpha]_{\mathrm{D}}-9.0(c 1.0, \mathrm{CHC}, 99 \% e e)$; The enantiomeric excess was determined by ${ }^{13} \mathrm{C}-\mathrm{NMR}$ $\left(100 \mathrm{MHz}, \mathrm{CDCl}_{3}\right)$ of the ketal, only one isomer was observed when transmethanoproline was used as catalyst; $[\alpha]_{\mathrm{D}}-8.4\left(c 1.0, \mathrm{CHCl}_{3}, 90 \%\right.$ ee $)$; The enantiomeric excess was determined by ${ }^{13} \mathrm{C}-\mathrm{NMR}(100 \mathrm{MHz}, \mathrm{CDC} \xi)$ of the ketal observing at $\delta$ 43.3/42.8, 39.2/38.1 and 36.6/35.5 when L-proline was used as catalyst; $[\alpha]_{\mathrm{D}}-6.6(c$ 1.0, $\mathrm{CHCl}_{3}, 76 \%$ ee); The enantiomeric excess was determined by ${ }^{13} \mathrm{C}-\mathrm{NMR}(100 \mathrm{MHz}$, $\mathrm{CDCl}_{3}$ ) of the ketal, observing at $\delta 43.3 / 42.8,39.2 / 38.1$ and $36.5 / 35.5$ when cismetha noproline was used as catalyst.

\section{3-(1-Nitrocyclohexyl) cyclohexanone}

$[\alpha]_{\mathrm{D}}+2.4(c 1.0, \mathrm{CHCb}, 99 \%$ ee $)$; The enantiomeric excess was determined by ${ }^{13} \mathrm{C}-\mathrm{NMR}$ $\left(100 \mathrm{MHz}, \mathrm{CDCl}_{3}\right)$ of the ketal, only one isomer was observed when transmethanoproline was used as catalyst; $[\alpha]_{\mathrm{D}}+2.2\left(c 1.0, \mathrm{CHCl}_{3}, 92 \%\right.$ ee $)$; The enantiomeric excess was determined by ${ }^{13} \mathrm{C}-\mathrm{NMR}(100 \mathrm{MHz}, \mathrm{CDC}$ ) $)$ of the ketal, observing at $\delta$ $44.4 / 43.8,37.8 / 36.7,36.3 / 35.3$ and $31.1 / 31.1$ when L-proline was used as catalyst); $[\alpha]_{\mathrm{D}}$ +1.8 ( $c 1.0, \mathrm{CHCb}, 74 \%$ ee $)$; The enantiomeric excess was determined by ${ }^{13} \mathrm{C}-\mathrm{NMR}$ (100 $\mathrm{MHz}, \mathrm{CDCl}_{3}$ ) of the ketal, observing at $\delta 43.9 / 43.4,38.1 / 37.0$ and 36.4/35.3 when cismethanoproline was used as catalyst. 


\section{3-(2-Nitropropane -2-yl) cyclopentanone}

$[\alpha]_{\mathrm{D}}+88.2$ (c 1.1, $\mathrm{CHCl}_{3}, 80 \% e e$ ) ; The enantiomeric excess was determined by ${ }^{13} \mathrm{C}$ NMR (100 MHz, $\mathrm{CDCl}_{3}$ ) of the ketal, observing at $\delta 46.0 / 45.6,39.4 / 39.2,37.2 / 37.0$ and 24.9/24.6 when trans-methanoproline was used as catalyst; $[\alpha]_{\mathrm{D}}+77.6(c) 1.0, \mathrm{CHCl}_{3}$, $69 \%$ ee); The enantiomeric excess was determined by ${ }^{13} \mathrm{C}-\mathrm{NMR}\left(100 \mathrm{MHz}, \mathrm{CDCl}_{3}\right)$ of the ketal, observing at $\delta 46.0 / 45.6,39.4 / 39.2,37.2 / 37.0$ and 24.9/24.6 when L-proline was used as catalyst; $[\alpha]_{\mathrm{D}}+76.0\left(c 1.0, \mathrm{CHCl}_{3}, 66 \% e e\right)$; The enantiomeric excess was determined by ${ }^{13} \mathrm{C}-\mathrm{NMR}\left(100 \mathrm{MHz}, \mathrm{CDCl}_{3}\right)$ of the ketal, observing at $\delta$ 46.0/46.6, 39.4/39.2, 37.2/37.0 and 24.9/24.6 when cis-methanoproline was used as catalyst.

\section{3-(1-Nitrocyclopentyl) cyclopentanone}

$[\alpha]_{\mathrm{D}}+78.5\left(\mathrm{c} 1.6, \mathrm{CHCl}_{3}, 87 \% e e\right)$; The enantiomeric excess was determined by ${ }^{13} \mathrm{C}$ NMR (100 MHz, $\mathrm{CDCl}_{3}$ ) of the ketal, observing at $\delta 44.3 / 44.0,40.1 / 39.9$ and 37.1/36.9 when trans-methanoproline was used as catalyst; $[\alpha]_{\mathrm{D}}+74.0\left(c 1.0, \mathrm{CHCl}_{3}, 76 \%\right.$ ee $)$; The enantiomeric excess was determined by ${ }^{13} \mathrm{C}-\mathrm{NMR}\left(100 \mathrm{MHz}, \mathrm{CDCl}_{3}\right)$ of the ketal, observing at $\delta 44.3 / 44.0,40.1 / 39.8$ and 37.1/36.9 when L-proline was used as catalyst;


NMR (100 MHz, $\mathrm{CDCl}_{3}$ ) of the ketal, observing at $\delta 44.3 / 44.0,40.1 / 39.9$ and 37.1/36.9 when cis-methanoproline was used as catalyst.

\section{3-(1-Nitrocyclohexyl) cyclopentanone}

$[\alpha]_{\mathrm{D}}+68.1\left(c 1.0, \mathrm{CHCl}_{3}, 83 \% e e\right)$; The enantiomeric excess was determined by ${ }^{13} \mathrm{C}$ NMR (100 MHz, $\mathrm{CDCl}_{3}$ ) of the ketal, observing at $\delta 46.9 / 46.4,38.7 / 38.4$ and 36.9/36.6 when trans-methanoproline was used as catalyst; $[\alpha]_{\mathrm{D}}+63.7\left(c 0.4, \mathrm{CHCl}_{3}, 77 \%\right.$ ee $)$; The enantiomeric excess was determined by ${ }^{13} \mathrm{C}-\mathrm{NMR}\left(100 \mathrm{MHz}, \mathrm{CDCl}_{3}\right)$ of the ketal, observing at $\delta$ 47.1/46.6, 38.9/38.6 and 37.1/36.8 when L-proline was used as catalyst; $[\alpha]_{\mathrm{D}}+59.1\left(c 0.7, \mathrm{CHCl}_{3}, 76 \% e e\right)$; The enantio meric excess was determined by ${ }^{13} \mathrm{C}$ - 
NMR (100 MHz, $\mathrm{CDCl}_{3}$ ) of the ketal, observing at $\delta 47.1 / 46.6,38.9 / 38.6$ and 37.1/36.8 when cis-methanoproline was used as catalyst.

\section{3-(2-Nitropropane -2-yl) cycloheptanone}

$[\alpha]_{\mathrm{D}}+77.7$ (c 1.0, $\mathrm{CHCl}_{3}, 99 \% e e$ ) ; The enantio meric excess was determined by ${ }^{13} \mathrm{C}-$ NMR (100 MHz, $\left.\mathrm{CDCl}_{3}\right)$ of the ketal, only one isomer was observed when transmethanoproline was used as catalyst; $[\alpha]_{\mathrm{D}}+66.0$ (c 1.2, $\mathrm{CHCl}_{3}, 84 \%$ ee); The enantiomeric excess was determined by ${ }^{13} \mathrm{C}-\mathrm{NMR}\left(100 \mathrm{MHz}, \mathrm{CDCl}_{3}\right)$ of the ketal, observing at at $\delta 110.2 / 109.5$ and $28.7 / 28.5$ when L-proline was used as catalyst; $[\alpha]_{\mathrm{D}}$ +38.5 ( $c 0.8, \mathrm{CHCl}_{3}, 60 \%$ ee); The enantiomeric excess was determined by ${ }^{13} \mathrm{C}-\mathrm{NMR}$ $\left(100 \mathrm{MHz}, \mathrm{CDCl}_{3}\right)$ of the ketal observing at $\delta 110.2 / 109.5$ and $28.9 / 28.5$ when cismethanoproline was used as catalyst.

\section{3-(1-Nitrocyclopentyl) cycloheptanone}

$[\alpha]_{\mathrm{D}}+48.0\left(c\right.$ 1.2, $\left.\mathrm{CHCl}_{3}, 99 \% e e\right)$; The enantiomeric excess was determined by ${ }^{13} \mathrm{C}$ NMR (100 MHz, $\left.\mathrm{CDCl}_{3}\right)$ of the ketal, only one isomer was observed when trans-


enantiomeric excess was determined by ${ }^{13} \mathrm{C}-\mathrm{NMR}\left(100 \mathrm{MHz}, \mathrm{CDCl}_{3}\right)$ of the ketal, observing at at $\delta 110.5 / 109.6,35.7 / 35.1$ and 22.1/21.5 when L-proline was used as catalyst; $[\alpha]_{\mathrm{D}}+27.2\left(c 1.3, \mathrm{CHCl}_{3}, 59 \%\right.$ ee); The enantiomeric excess was determined by ${ }^{13} \mathrm{C}-\mathrm{NMR}\left(100 \mathrm{MHz}, \mathrm{CDCl}_{3}\right)$ of the ketal, observing at $\delta 110.5 / 109.7,35.7 / 35.1$ and 22.1/21.5 when cis-methanoproline was used as catalyst.

\section{3-(1-Nitrocyclohexyl) cycloheptanone}

$[\alpha]_{\mathrm{D}}+50.1\left(c 1.2, \mathrm{CHCl}_{3}, 99 \% e e\right)$; The enantiomeric excess was determined by ${ }^{13} \mathrm{C}-$ NMR (100 MHz, $\left.\mathrm{CDCl}_{3}\right)$ of the ketal, only one isomer was observed when trans-

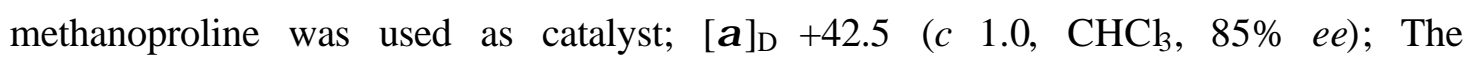
enantiomeric excess was determined by ${ }^{13} \mathrm{C}-\mathrm{NMR}\left(100 \mathrm{MHz}, \mathrm{CDCl}_{3}\right)$ of the ketal, observing at at $\delta 110.2 / 109.4,28.4 / 27.9$ and 26.2/24.7 when L-proline was used as 
catalyst; $[\alpha]_{\mathrm{D}}+18.7\left(c 0.6, \mathrm{CHCl}_{3}, 61 \%\right.$ ee); The enantiomeric excess was determined by ${ }^{13} \mathrm{C}-\mathrm{NMR}\left(100 \mathrm{MHz}, \mathrm{CDCl}_{3}\right)$ of the ketal, observing at $\delta 110.3 / 109.4,28.4 / 27.9$ and 26.3/24.7 when cis- methanoproline was used as catalyst.

\section{3-Nitromethyl cyclohexanone}

$[\alpha]_{\mathrm{D}}+6.9\left(c 1.5, \mathrm{CHCb}_{3}, 74 \%\right.$ ee $)$; The enantiomeric excess was determined by ${ }^{13} \mathrm{C}-\mathrm{NMR}$ $\left(100 \mathrm{MHz}, \mathrm{CDCl}_{3}\right)$ of the ketal, observing at $\delta 40.1 / 39.4,36.4 / 35.5,34.7 / 34.4$ and 22.0/21.6 when trans-methanoproline was used as catalyst; $[\alpha]_{\mathrm{D}}+6.6\left(c 1.3, \mathrm{CHCl}_{3}, 71 \%\right.$ $e e$ ); The enantiomeric excess was determined by ${ }^{13} \mathrm{C}-\mathrm{NMR}\left(100 \mathrm{MHz}, \mathrm{CDCl}_{3}\right)$ of the ketal, observing at $\delta 40.1 / 39.3,36.4 / 35.5,34.7 / 34.4$ and 22.0/21.6 when L-proline was used as catalyst.

\section{3-Nitromethyl cyclopentanone}

$[\alpha]_{\mathrm{D}}+66.0\left(c 1.5, \mathrm{CHCl}_{3}, 61 \% e e\right)$; The enantiomeric excess was determined by ${ }^{13} \mathrm{C}-$ NMR (100 MHz, $\mathrm{CDCl}_{3}$ ) of the ketal, observing at $\delta 41.4 / 41.0,36.8 / 36.5,35.4 / 35.1$ and 27.2/26.8 when trans-methanoproline was used as catalyst; $[\alpha]_{\mathrm{D}}+62.0\left(c 1.4, \mathrm{CHCl}_{3}\right.$, $57 \%$ ee); The enantiomeric excess was determined by ${ }^{13} \mathrm{C}-\mathrm{NMR}(100 \mathrm{MHz}, \mathrm{CDCb})$ of the ketal, observing at $\delta 41.4 / 41.1,36.8 / 36.5,35.4 / 35.1$ and 27.2/26.8 when L-proline was used as catalyst.

\section{3-(5-Nitropentene) cyclo hexanone (Less polar), 9}

$[\alpha]_{\mathrm{D}}+18.5\left(c 1.0, \mathrm{CHCl}_{3}, 84 \% e e\right)$; The enantiomeric excess was determined by ${ }^{13} \mathrm{C}$ NMR of the ketal, observing at $\delta 36.5 / 35.5$ and 22.1/21.7 when L-proline was used as catalyst.

3-(5-Nitropentene) cyclohexanone (More polar), 10

$[\alpha]_{\mathrm{D}}-9.9\left(c 1.0, \mathrm{CHCl}_{3}, 70 \% e e\right)$; The enantiomeric excess was determined by ${ }^{13} \mathrm{C}-\mathrm{NMR}$ of the ketal, observing at $\delta 36.5 / 35.5$ and 22.4/22.0 when L-proline was used as catalyst. 
3-(5-Nitropentene) cyclopentane (Less polar)

$[\alpha]_{\mathrm{D}}+80.9\left(c 1.2, \mathrm{CHCl}_{3}, 76 \% e e\right)$; The enantiomeric excess was determined by ${ }^{13} \mathrm{C}-$ NMR of the ketal, observing at $\left(100 \mathrm{MHz}, \mathrm{CDCl}_{3}\right) \delta 36.9 / 36.6$ and 27.1/26.6 when transmethanoproline was used as catalyst; $[\alpha]_{\mathrm{D}}+76.0 \quad\left(c 1.0, \mathrm{CHCl}_{3}, 70 \%\right.$ ee $)$; The enantiomeric excess was determined by ${ }^{13} \mathrm{C}-\mathrm{NMR}$ of the ketal, observing at $\delta 36.9 / 36.6$ and 27.1/26.6 when L-proline was used as catalyst.

\section{3-(5-Nitropentene) cyclopentane (More polar)}

$[\alpha]_{\mathrm{D}}+54.6\left(c 1.0, \mathrm{CHCl}_{3}, 60 \% e e\right)$; The enantiomeric excess was determined by ${ }^{13} \mathrm{C}$ NMR of the ketal, observing at $\left(100 \mathrm{MHz}, \mathrm{CDCl}_{3}\right) \delta 37.1 / 36.8$ and 26.5/26.2 when transmethanoproline was used as catalyst; $[\alpha]_{\mathrm{D}}+48.1$ (c 1.0, $\mathrm{CHCl}_{3}, 50 \%$ ee); The enantiomeric excess was determined by ${ }^{13} \mathrm{C}-\mathrm{NMR}$ of the ketal, observing at $\delta 37.1 / 36.8$ and 26.5/26.2 when L-proline was used as catalyst.

\section{3-(1-Nitro-propyl)-cyclohexanone (Less polar)}

$[\alpha]_{\mathrm{D}}+27.7\left(c 1.0, \mathrm{CHCl}_{3}, 85 \% e e\right.$ ) ; The enantiomeric excess was determined by ${ }^{13} \mathrm{C}$ NMR of the ketal, observing at $\left(100 \mathrm{MHz}, \mathrm{CDCl}_{3}\right) \delta$ when L-proline was used as catalyst.

\section{3-(1-Nitro-propyl)-cyclohexanone (More polar)}

$[\alpha]_{\mathrm{D}}-13.0\left(c 1.0, \mathrm{CHCl}_{3}, 72 \% e e\right)$; The enantiomeric excess was determined by ${ }^{13} \mathrm{C}-\mathrm{NMR}$ of the ketal, observing at $\left(100 \mathrm{MHz}, \mathrm{CDCl}_{3}\right) \delta$ when L-proline was used as catalyst. 


\section{Supporting Information - Table of Ketals}





2, $\mathrm{n}=1$
3, $\mathrm{n}=2$

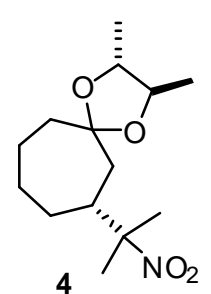

$\mathrm{NO}_{2}$

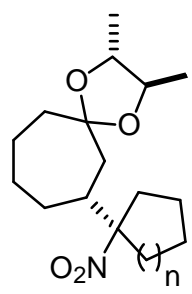

$5, \mathrm{n}=1$



from less polar ketone

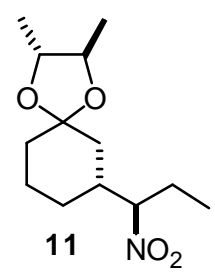

from less polar ketone

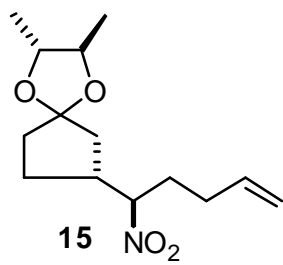

from less polar ketone



from more polar ketone

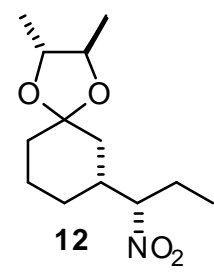

from more polar ketone

from more polar ketone

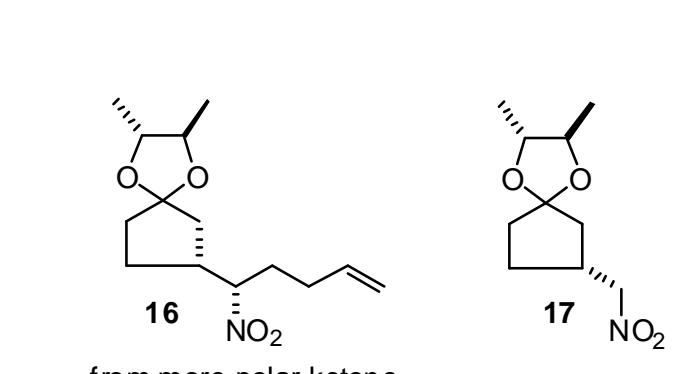<smiles>C=CCCC([C@H]1CCCC(=O)C1)[N+](=O)[O-]</smiles>

less polar

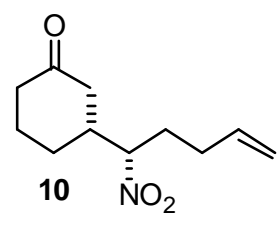

more polar
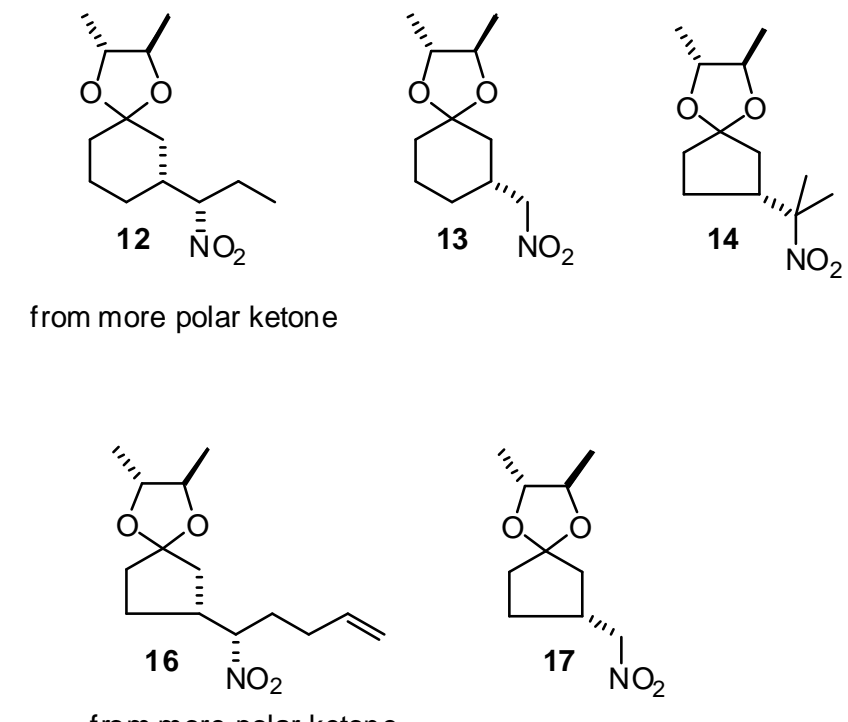

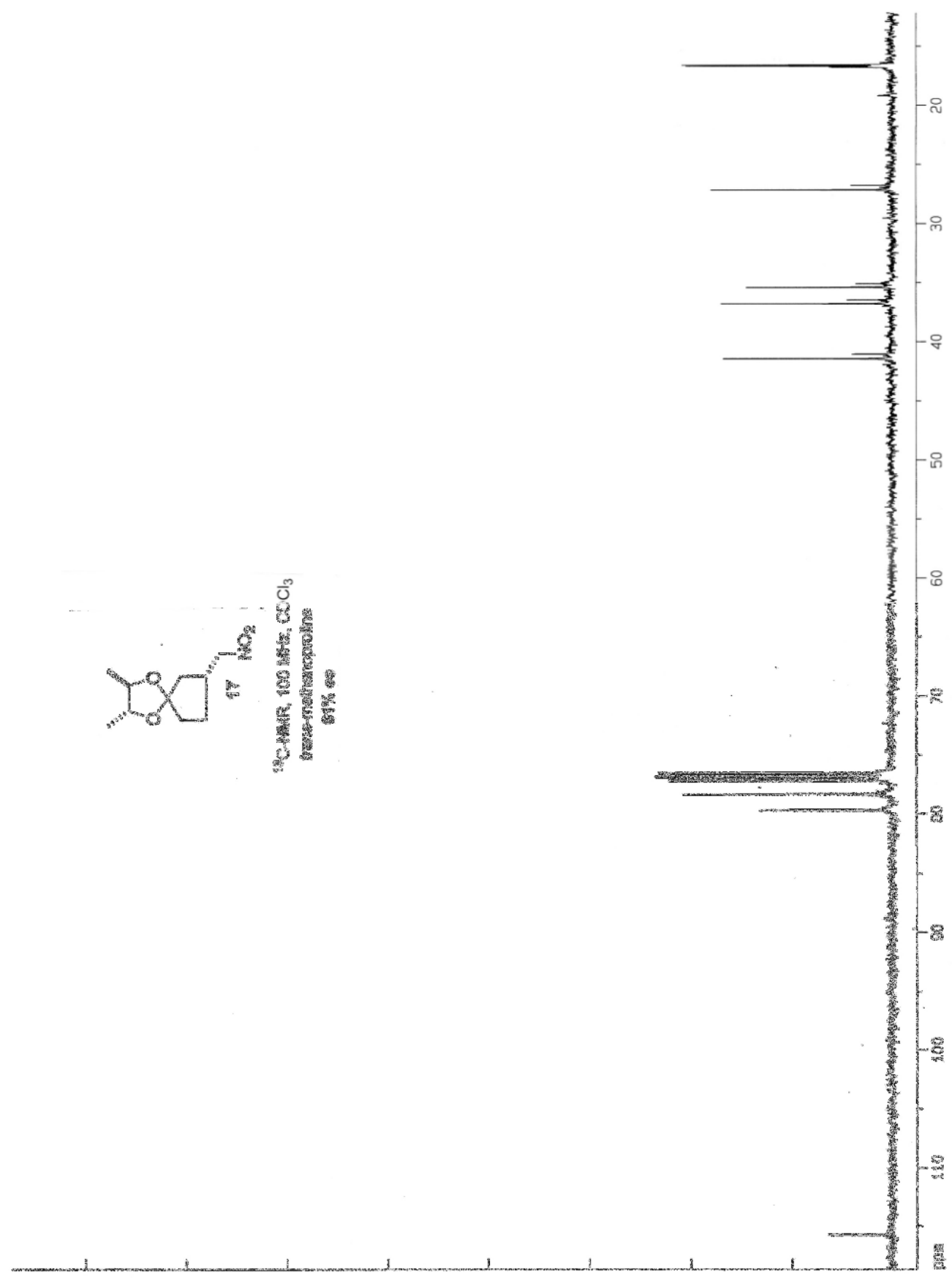
S 16
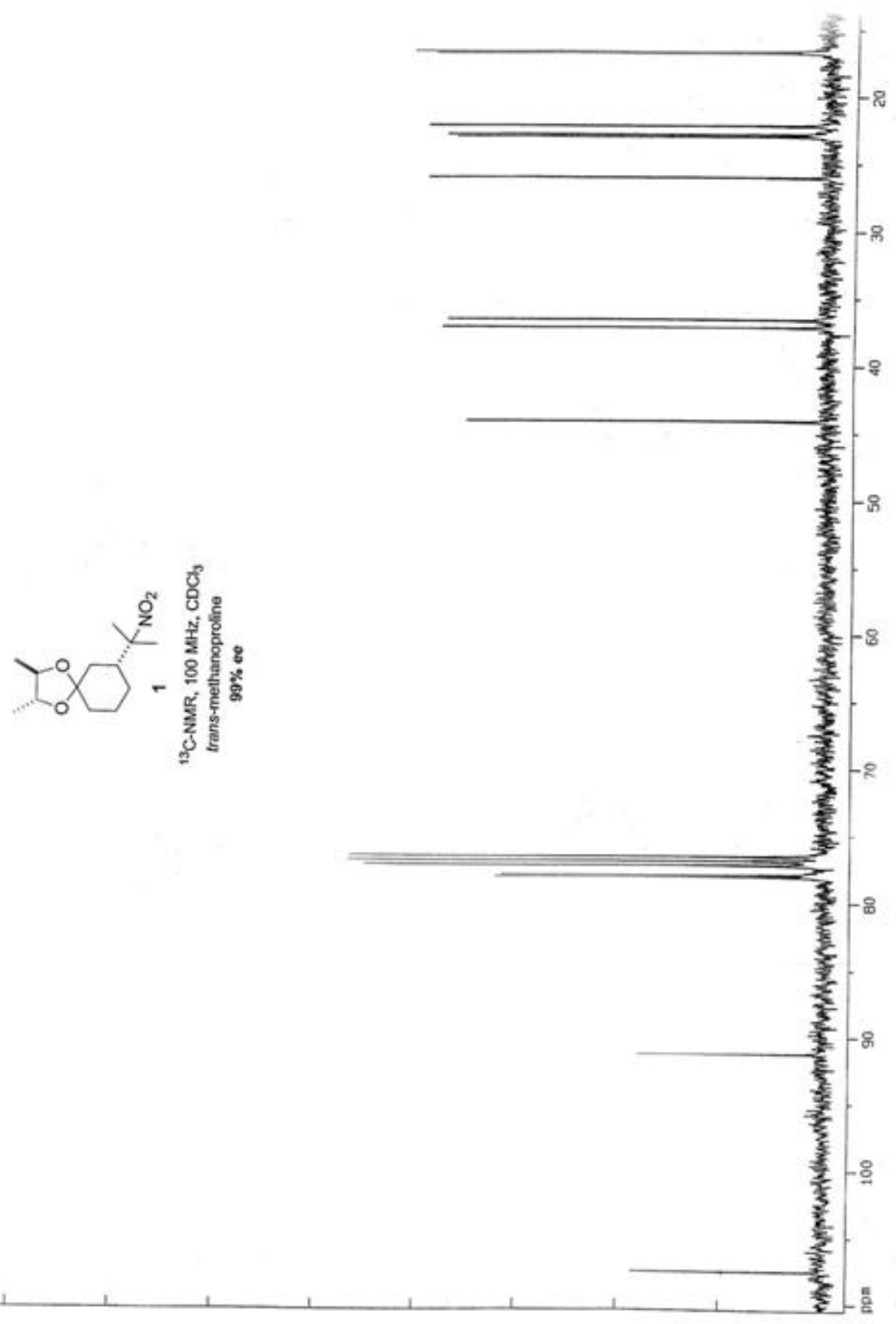

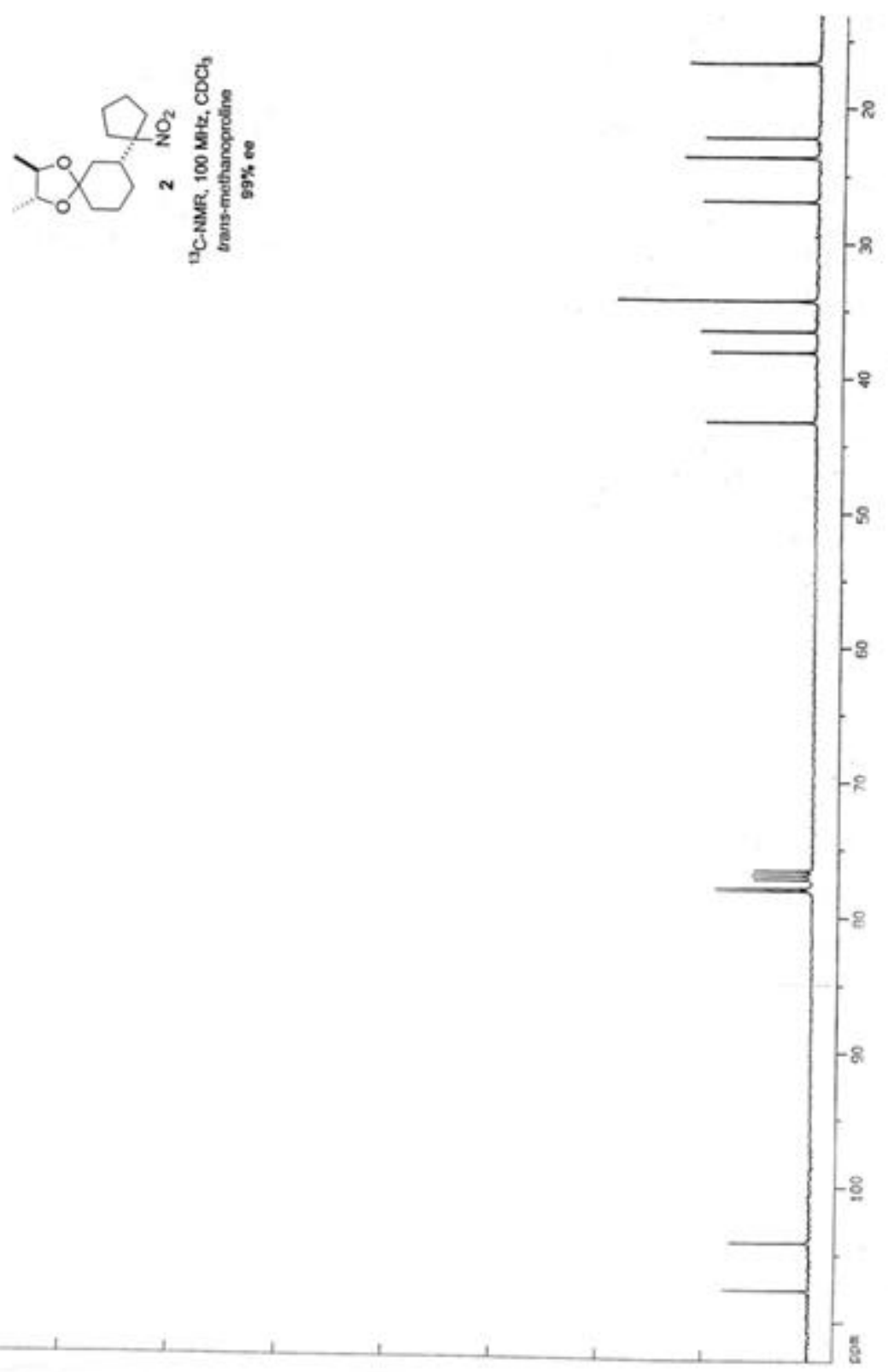







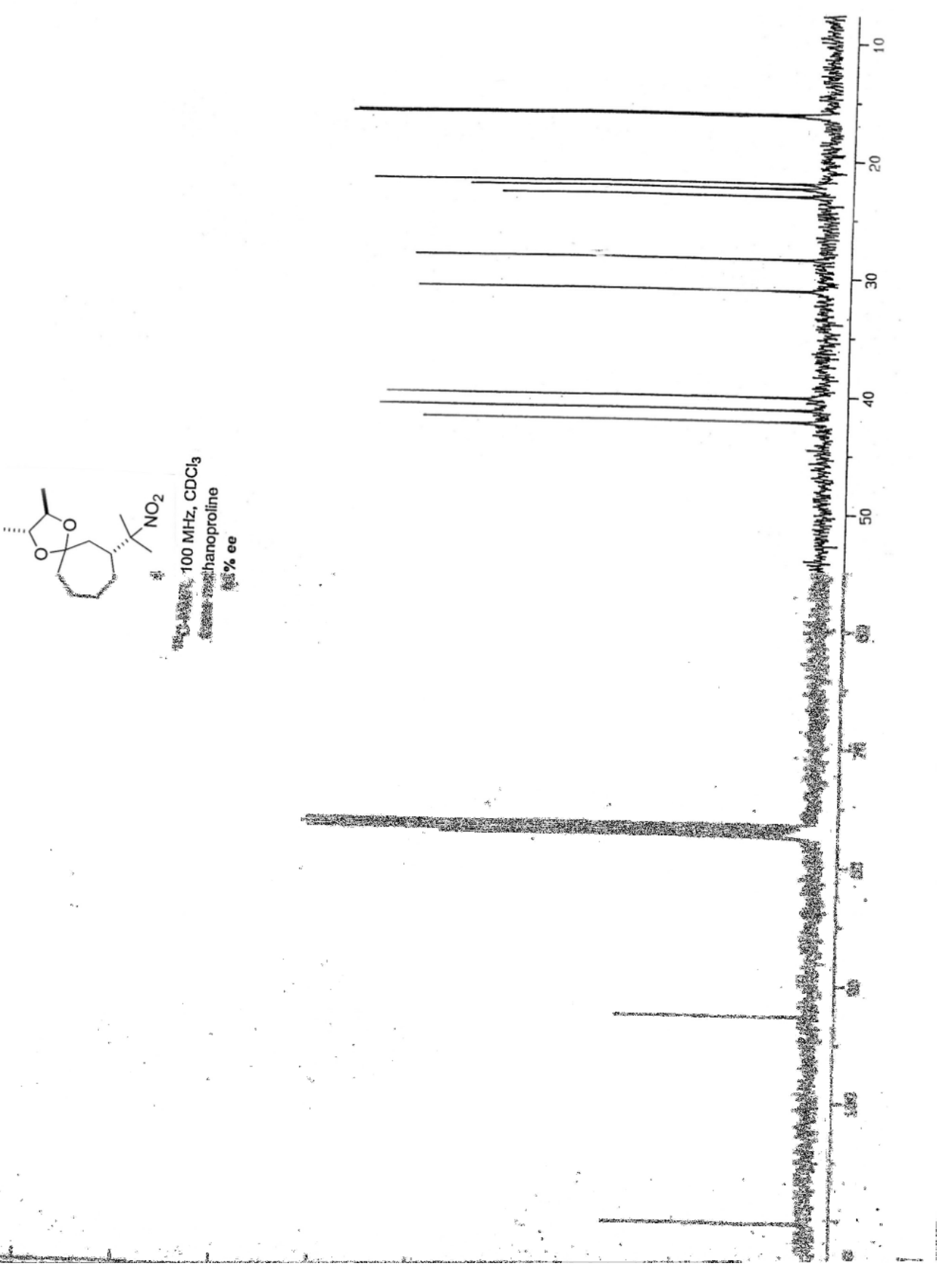



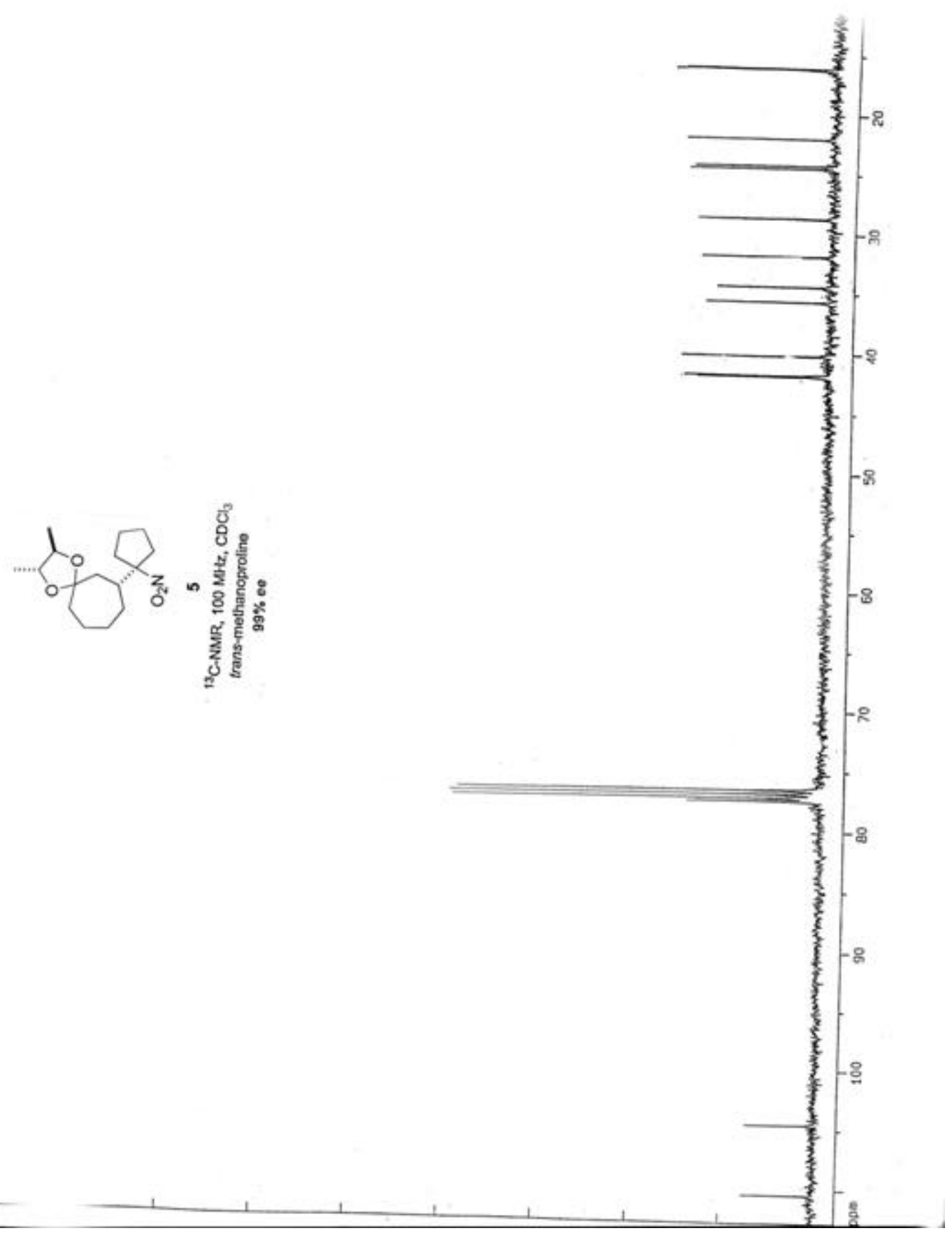
S 21

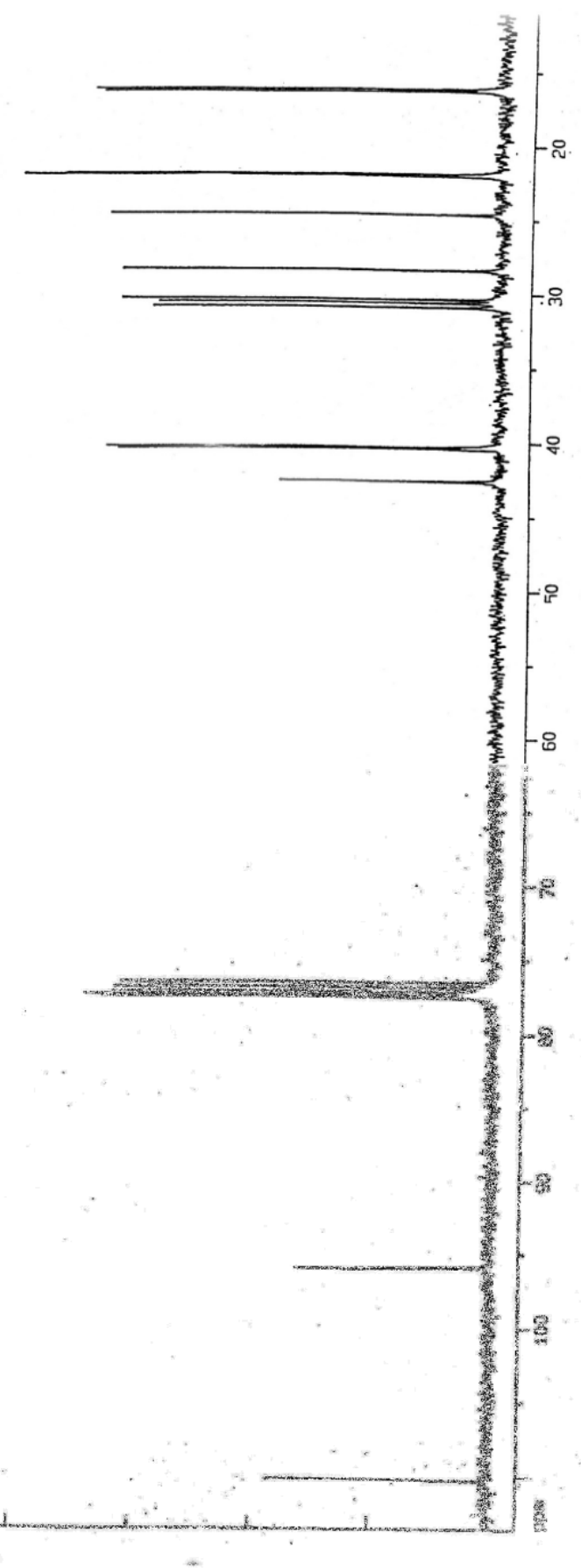




$$
\text { 㖀 }
$$



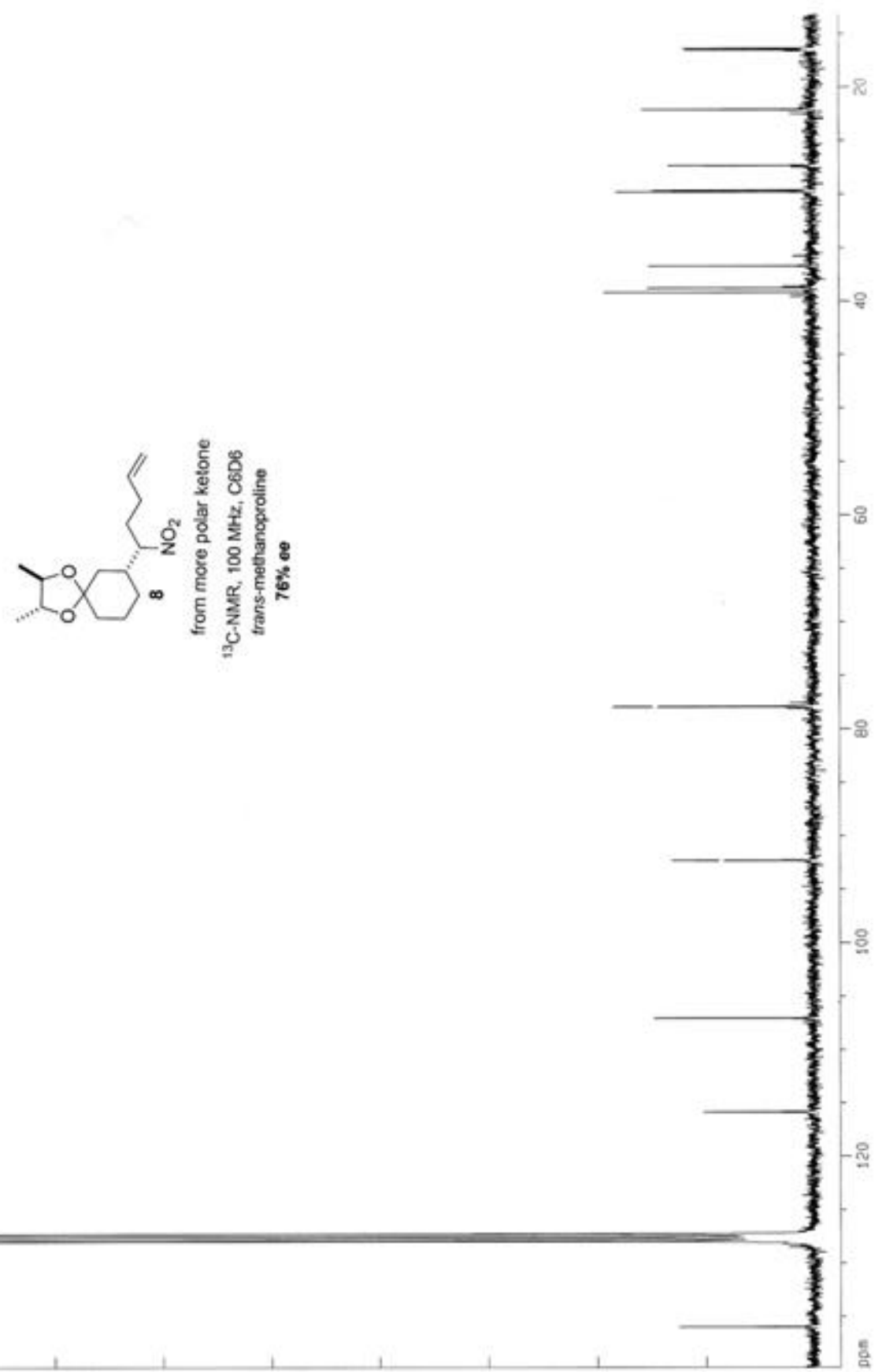




$$
\text { 斗 }
$$




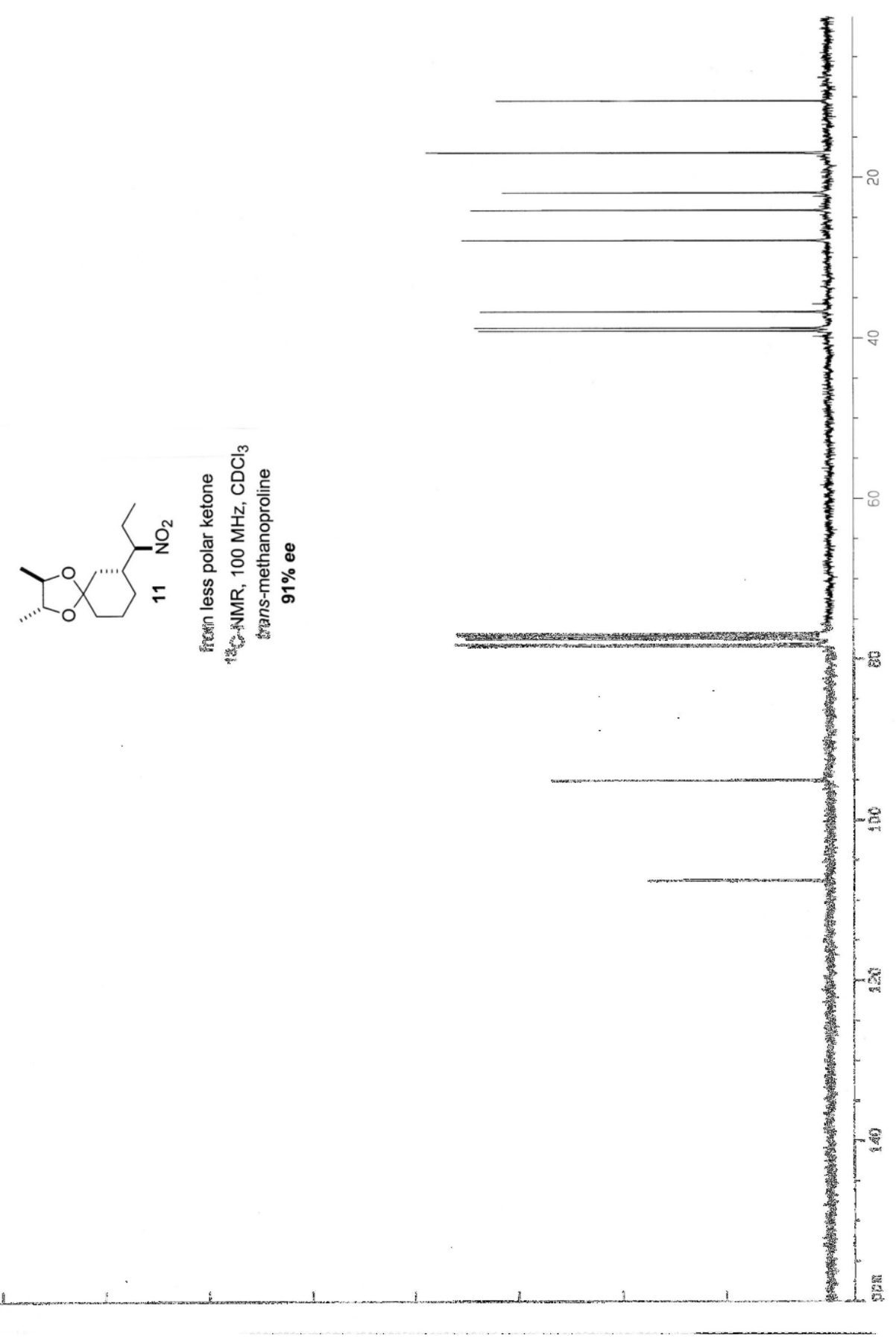



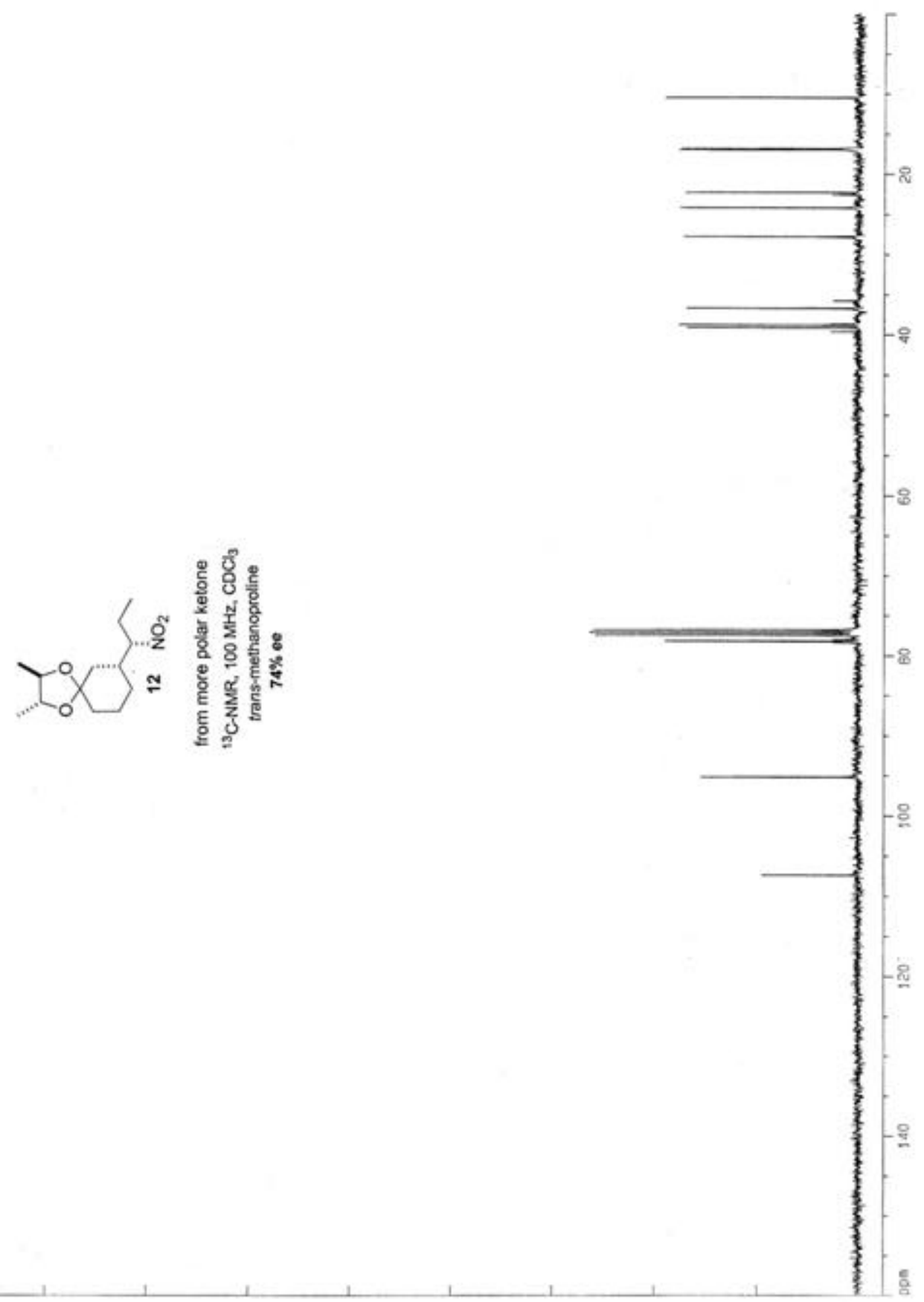
$x_{0}^{0} \longrightarrow=\frac{1}{2}$

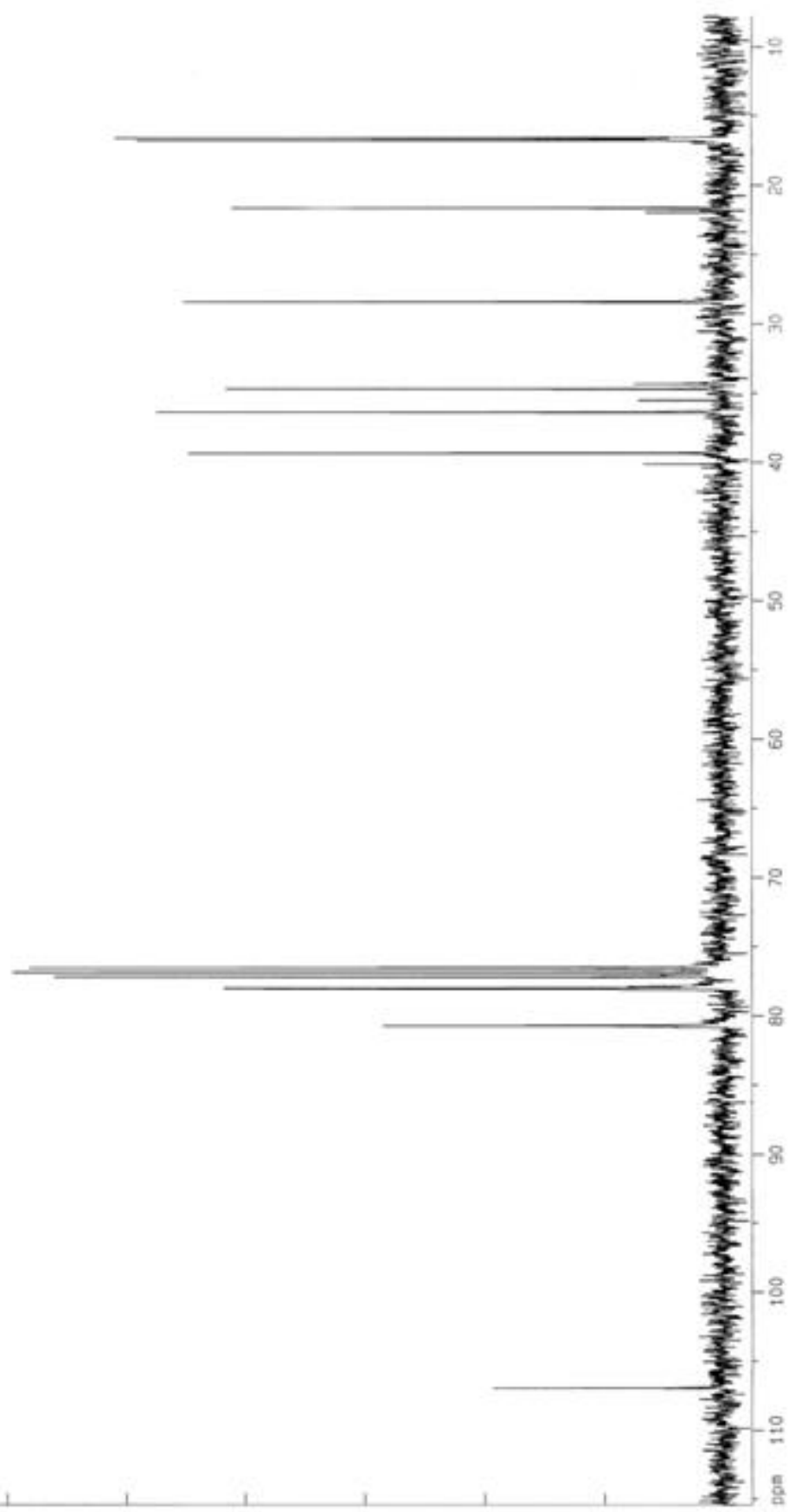




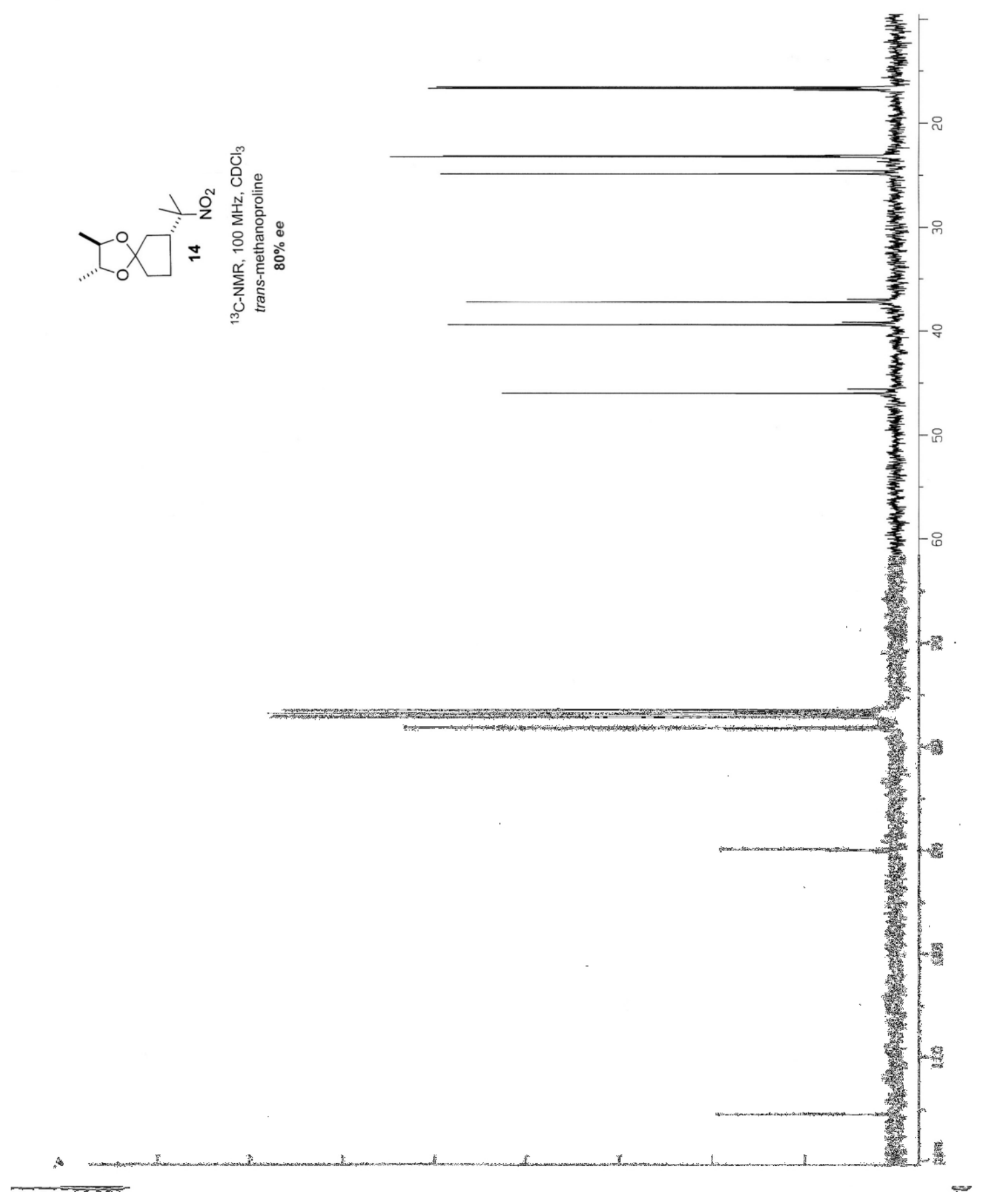



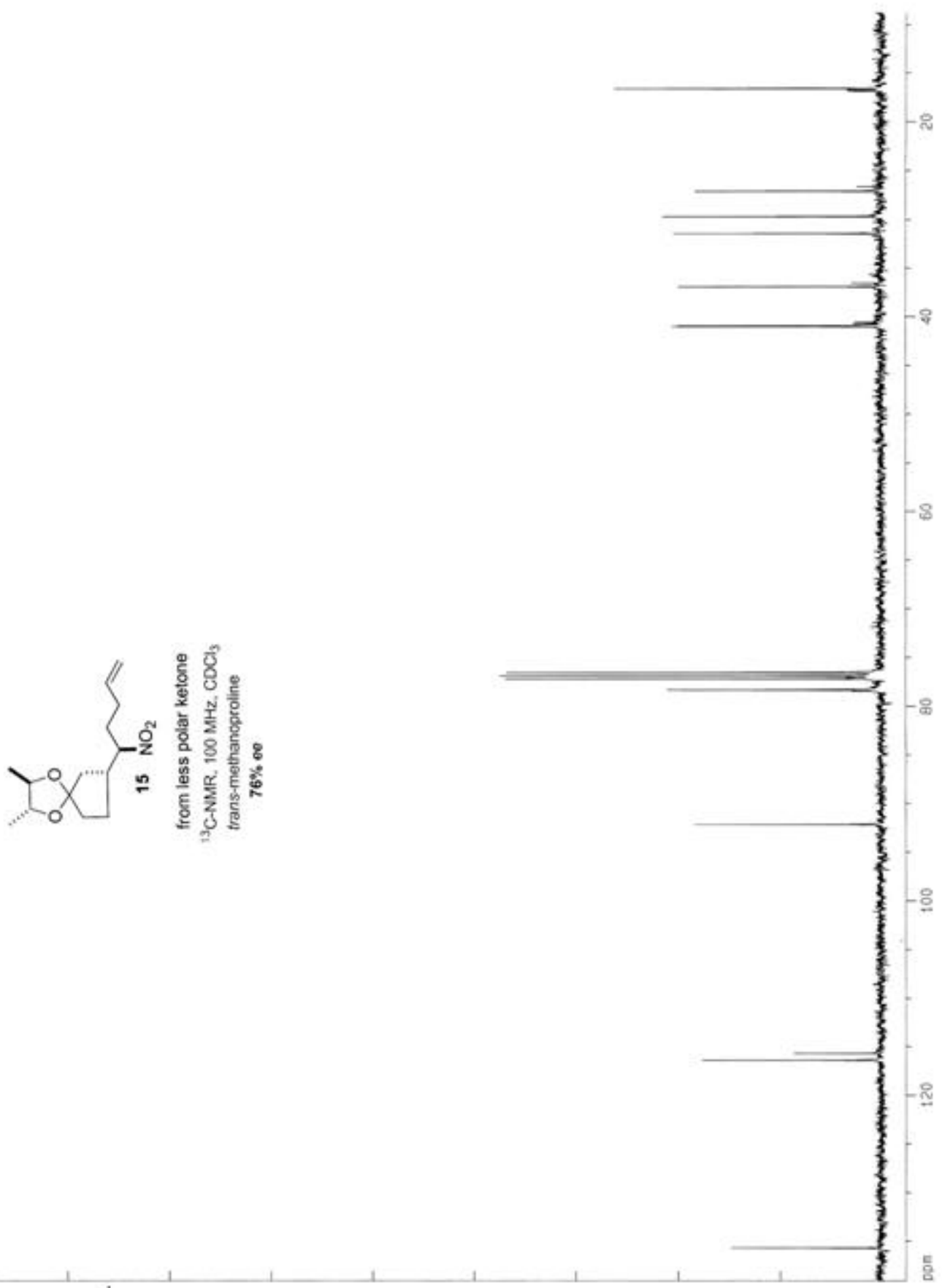

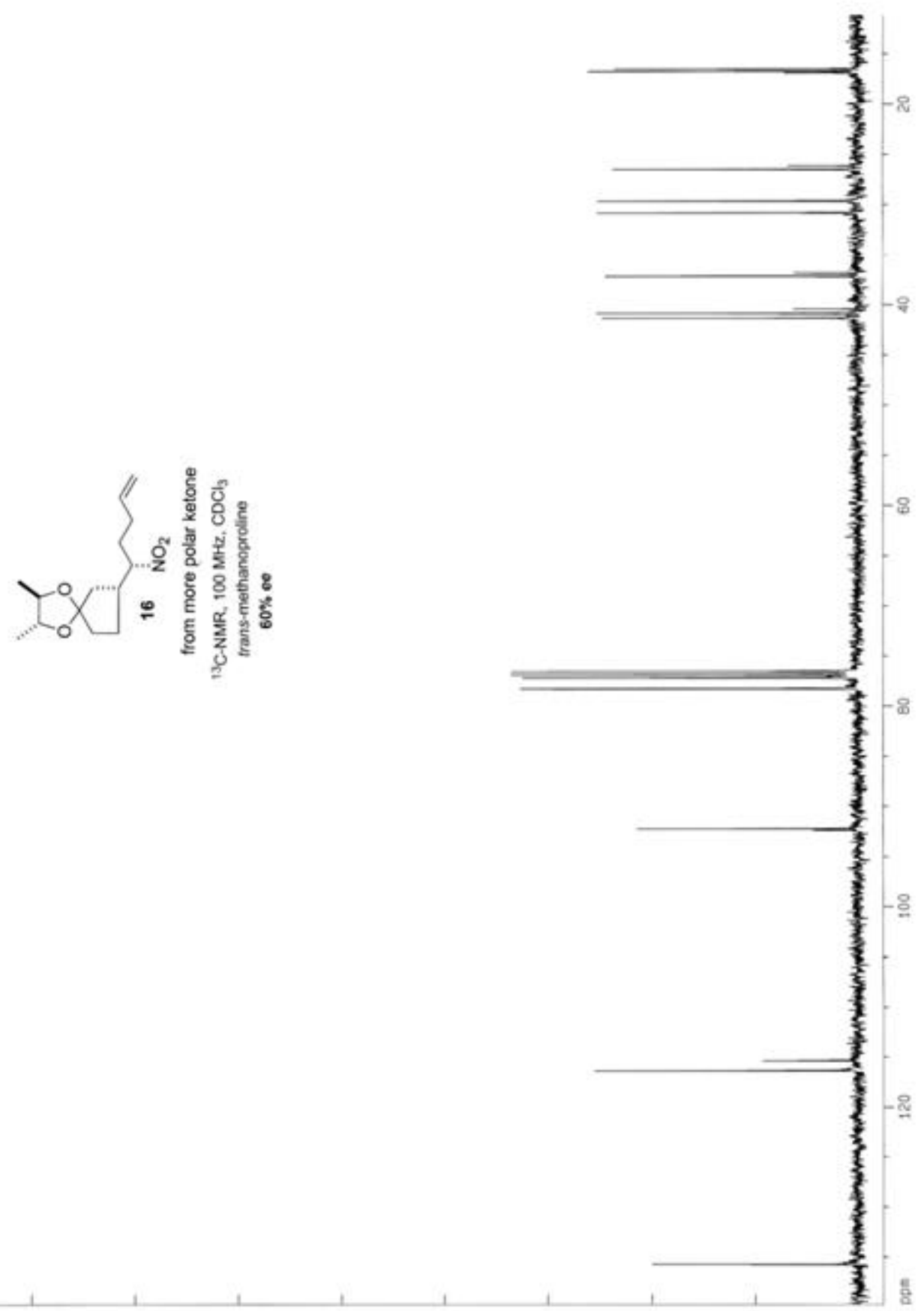


CRYSTAL AND MOLECULAR STRUCTURE OF C6 H9 N 02 COMPOUND (HAN227)

Equipe HANESSIAN

Département de chimie, Université de Montréal, C.P. 6128, Succ. Centre-Vilie, Montréa1, Québec, H3C $3 J 7$ (Canada)<smiles>OC(O)C1C[C@@H]2C[C@H]2[NH2+]1</smiles>

Structure résolue au iaboratoire de diffraction des rayons $\mathrm{x}$ de l'université de Montréal par Dr. Michel Simard. 


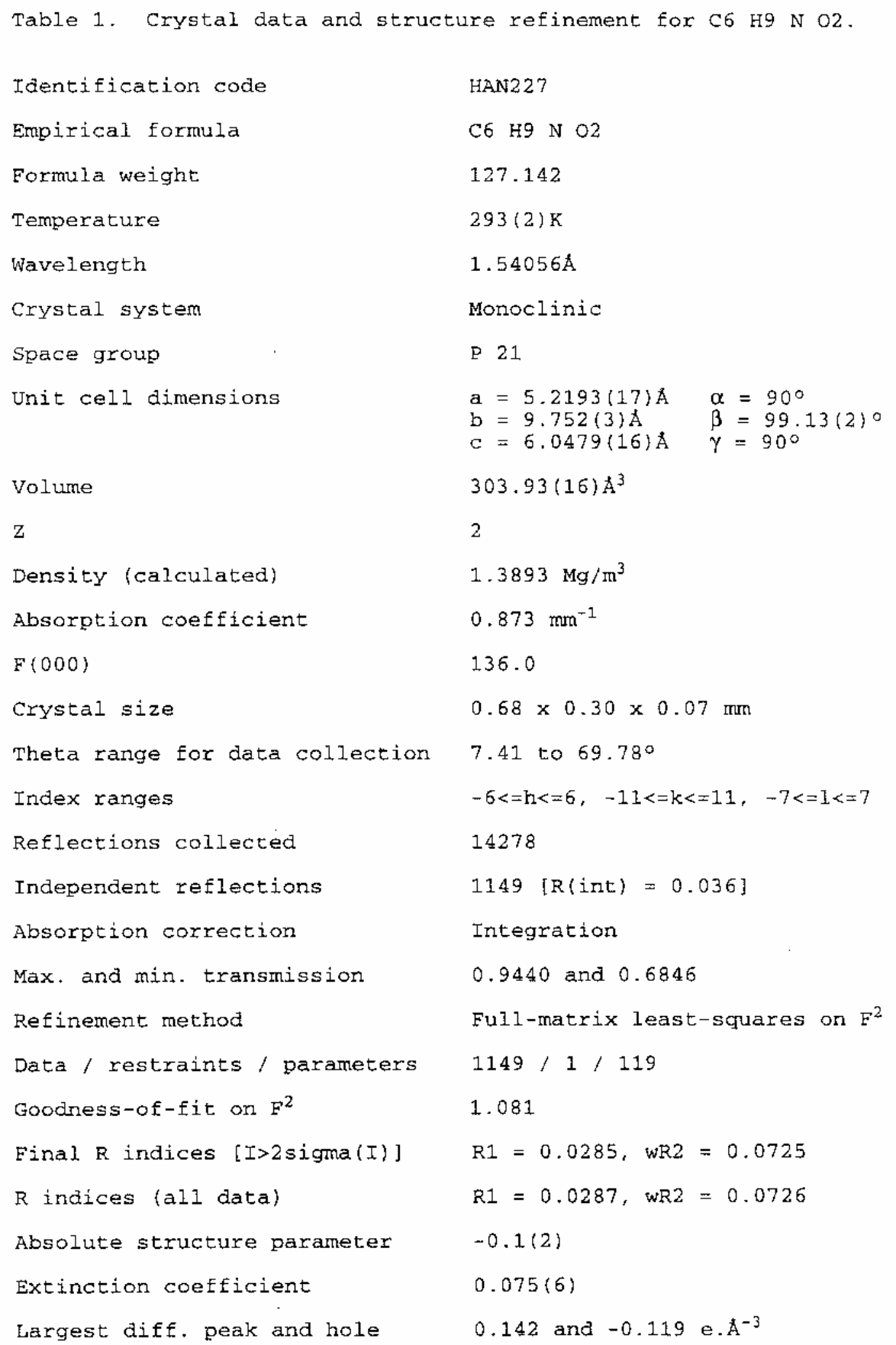


Table 2. Atomic coordinates $\left(x 10^{4}\right)$ and equivalent isotropic displacement parameters $\left(A^{2} \times 10^{3}\right)$ for $\mathrm{C} 6 \mathrm{Ha} \mathrm{NO}$.

U(eg) is defined as one third of the trace of the orthogonalized Uij tensor.

\begin{tabular}{lrrrr}
\hline & $x$ & $y$ & $z$ & $U($ eq) \\
\hline & & & & \\
\hline$(1)$ & $12047(2)$ & $1918(1)$ & $5254(2)$ & $37(1)$ \\
$O(2)$ & $12481(2)$ & $-330(1)$ & $4896(2)$ & $53(1)$ \\
$N(2)$ & $6880(2)$ & $1922(1)$ & $4043(2)$ & $27(1)$ \\
$C(1)$ & $6065(3)$ & $2201(1)$ & $1644(2)$ & $37(1)$ \\
$C(3)$ & $8223(2)$ & $559(1)$ & $4269(2)$ & $26(1)$ \\
$C(4)$ & $7299(3)$ & $-189(2)$ & $2057(2)$ & $40(1)$ \\
$C(5)$ & $6316(3)$ & $908(2)$ & $377(2)$ & $42(1)$ \\
$C(6)$ & $8108(3)$ & $2099(2)$ & $196(3)$ & $50(1)$ \\
$C(7)$ & $11174(2)$ & $734(1)$ & $4848(2)$ & $29(1)$ \\
\hline
\end{tabular}


S 36

Table 3. Hydrogen coordinates $\left(x 10^{4}\right)$ and isotropic displacement parameters $\left(\mathrm{A}^{2} \times 10^{3}\right)$ for $\mathrm{C} 6 \mathrm{Hg} \mathrm{N} O 2$.

\begin{tabular}{lrrrr}
\hline & $x$ & $y$ & $z$ & U(eq) \\
\hline$H(2 A)$ & $5370(4)$ & $1900(2)$ & $4620(3)$ & $48(5)$ \\
$H(2 B)$ & $8000(4)$ & $2570(2)$ & $4750(3)$ & $41(5)$ \\
$H(1)$ & $4700(5)$ & $2840(2)$ & $1360(3)$ & $45(5)$ \\
$H(3)$ & $7660(3)$ & $109(19)$ & $5440(3)$ & $33(4)$ \\
$H(4 A)$ & $8720(5)$ & $-700(3)$ & $1680(4)$ & $58(6)$ \\
$H(4 B)$ & $5920(5)$ & $-770(3)$ & $2300(4)$ & $62(6)$ \\
$H(5)$ & $5000(5)$ & $600(3)$ & $-960(4)$ & $65(6)$ \\
$H(6 A)$ & $9960(4)$ & $2020(2)$ & $950(3)$ & $53(5)$ \\
$H(6 B)$ & $7830(4)$ & $2650(2)$ & $-1170(4)$ & $56(6)$ \\
\hline
\end{tabular}


Table 4. Anisotropic parameters $\left(\mathrm{A}^{2} \times 10^{3}\right)$ for $\mathrm{C6}$ H9 $\mathrm{N}$ O2.

The anisotropic displacement factor exponent takes the form:

$-2 \pi^{2}\left[h^{2} a^{* 2} \mathrm{U} 11+\ldots+2 h k a^{*} b^{*} \mathrm{U} 12\right]$

\begin{tabular}{rrrrrrr}
\hline & U11 & U22 & U33 & U23 & U13 & U12 \\
\hline$O(1)$ & $23(1)$ & $34(1)$ & $55(1)$ & $-8(1)$ & $3(1)$ & $-3(1)$ \\
$O(2)$ & $27(1)$ & $30(1)$ & $101(1)$ & $12(1)$ & $6(1)$ & $6(1)$ \\
$\mathrm{N}(2)$ & $21(1)$ & $25(1)$ & $36(1)$ & $-1(1)$ & $4(1)$ & $0(1)$ \\
$\mathrm{C}(1)$ & $32(1)$ & $35(1)$ & $41(1)$ & $9(1)$ & $0(1)$ & $3(1)$ \\
$\mathrm{C}(3)$ & $22(1)$ & $24(1)$ & $32(1)$ & $2(1)$ & $4(1)$ & $0(1)$ \\
$\mathrm{C}(4)$ & $39(1)$ & $33(1)$ & $45(1)$ & $-9(1)$ & $-2(1)$ & $0(1)$ \\
$\mathrm{C}(5)$ & $39(1)$ & $51(1)$ & $33(1)$ & $-5(1)$ & $-1(1)$ & $-2(1)$ \\
$\mathrm{C}(6)$ & $47(1)$ & $66(1)$ & $37(1)$ & $13(1)$ & $7(1)$ & $-8(1)$ \\
$\mathrm{C}(7)$ & $21(1)$ & $30(1)$ & $35(1)$ & $5(1)$ & $4(1)$ & $1(1)$ \\
\hline
\end{tabular}


Table 5. Bond lengths $[\AA]$ and angles $\left[{ }^{\circ}\right]$ for $\mathrm{C} 6 \mathrm{H}^{\circ} \mathrm{N} O 2$

\begin{tabular}{llll}
\hline$O(1)-C(7)$ & $1.2520(19)$ & $O(2)-C(7)$ & \\
$N(2)-C(1)$ & $1.4710(17)$ & $N(2)-C(3)$ & $1.2389(17)$ \\
$C(1)-C(6)$ & $1.487(2)$ & $C(1)-C(5)$ & $1.4986(16)$ \\
$C(3)-C(4)$ & $1.5331(18)$ & $C(3)-C(7)$ & $1.492(2)$ \\
$C(4)-C(5)$ & $1.509(2)$ & $C(5)-C(6)$ & $1.5339(16)$ \\
$C(1)-N(2)-C(3)$ & $108.19(10)$ & $N(2)-C(1)-C(6)$ & $1.506(3)$ \\
$N(2)-C(1)-C(5)$ & $108.36(11)$ & $C(6)-C(1)-C(5)$ & $116.51(12)$ \\
$N(2)-C(3)-C(4)$ & $105.36(10)$ & $N(2)-C(3)-C(7)$ & $111.15(10)$ \\
$C(4)-C(3)-C(7)$ & $114.66(11)$ & $C(5)-C(4)-C(3)$ & $106.03(12)$ \\
$C(1)-C(5)-C(6)$ & $59.45(11)$ & $C(1)-C(5)-C(4)$ & $107.56(12)$ \\
$C(6)-C(5)-C(4)$ & $116.57(13)$ & $C(1)-C(6)-C(5)$ & $59.80(10)$ \\
$O(2)-C(7)-O(1)$ & $125.87(11)$ & $O(2)-C(7)-C(3)$ & $116.22(11)$ \\
$O(1)-C(7)-C(3)$ & $117.90(11)$ & &
\end{tabular}


Table 6. Torsion angles $\left[^{\circ}\right]$ for $\mathrm{C} 6 \mathrm{Hg} \mathrm{N} O 2$.

$\begin{array}{rr}C(3)-N(2)-C(1)-C(6) & -52.84(16) \\ C(3)-N(2)-C(1)-C(5) & 12.97(14) \\ C(1)-N(2)-C(3)-C(4) & -20.74(13) \\ C(1)-N(2)-C(3)-C(7) & 104.02(11) \\ N(2)-C(3)-C(4)-C(5) & 20.53(14) \\ C(7)-C(3)-C(4)-C(5) & -102.01(13) \\ N(2)-C(1)-C(5)-C(6) & -110.68(13) \\ N(2)-C(1)-C(5)-C(4) & 0.30(16) \\ C(6)-C(1)-C(5)-C(4) & 110.98(14) \\ C(3)-C(4)-C(5)-C(1) & -12.99(16) \\ C(3)-C(4)-C(5)-C(6) & 51.05(18) \\ N(2)-C(1)-C(6)-C(5) & -95.13(13) \\ C(4)-C(5)-C(6)-C(1) & -174.42(15) \\ N(2)-C(3)-C(7)-O(2) & -55.07(16) \\ C(4)-C(3)-C(7)-O(2) & 6.47(15) \\ N(2)-C(3)-C(7)-O(1) & 125.81(13) \\ C(4)-C(3)-C(7)-O(1) & \end{array}$


Table 7 . Bond lengths $[\mathrm{A}]$ and angles $\left[{ }^{\circ}\right]$ related to the hydrogen bonding for $\mathrm{C} 6 \mathrm{H} 9 \mathrm{~N} \mathrm{O} 2$.

\begin{tabular}{llllll}
\hline $\mathrm{D}-\mathrm{H}$ & $\mathrm{d}(\mathrm{D}-\mathrm{H})$ & $\mathrm{d}(\mathrm{H}, \mathrm{A})$ & $<\mathrm{DHA}$ & $\mathrm{d}(\mathrm{D} \ldots \mathrm{A})$ & $\ldots A$ \\
$\mathrm{~N}(2)-\mathrm{H}(2 \mathrm{~A})$ & $0.91(2)$ & $1.83(2)$ & $169.3(19)$ & $2.736(2)$ & $\mathrm{O}(1) \# 1$ \\
$\mathrm{~N}(2)-\mathrm{H}(2 \mathrm{~B})$ & $0.92(2)$ & $2.08(2)$ & $130.4(16)$ & $2.764(2)$ & $\mathrm{O}(2) \# 2$ \\
$\mathrm{~N}(2)-\mathrm{H}(2 \mathrm{~B})$ & $0.92(2)$ & $2.18(2)$ & $113.2(16)$ & $2.680(2)$ & $\mathrm{O}(1) \# 3$ \\
\hline
\end{tabular}

Symetry transformations used to generate equivalent atoms:

$$
\# 1 x-1, y, z \quad \# 2-x+2, y+1 / 2,-z+1 \quad \# 3 x, y, z
$$


Table 8. Distances to best planes for $\mathrm{C} 6 \mathrm{Hg} \mathrm{N} \mathrm{O} 2$.

Plane no. 1

$\begin{array}{lrll}* & 0.037 & (0.001) & \mathrm{C} 1 \\ * & -0.105 & (0.001) & \mathrm{N} 2 \\ * & 0.129 & (0.001) & \mathrm{C} 3 \\ * & -0.106 & (0.001) & \mathrm{C} 4 \\ * & 0.044 & (0.001) & \mathrm{C} 5\end{array}$

Rms deviation of fitted atoms $=0.092$

plane no. 2

$\begin{array}{rrrr}* & 0.074(0.000) & \mathrm{Cl} \\ * & -0.119(0.001) & \mathrm{N} 2 \\ * & 0.114(0.001) & \mathrm{C} 3 \\ * & -0.069(0.000) & \mathrm{C} 4 \\ & 0.112(0.002) & \mathrm{C} 5\end{array}$

Rms deviation of fitted atoms =

0.097

Plane no. 3

$\begin{array}{rrrr}* & 0.071 & (0.001) & \mathrm{C} \\ * & -0.071 & (0.001) & \mathrm{N} 2 \\ * & 0.043 & (0.000) & \mathrm{C3} \\ * & -0.043 & (0.000) & \mathrm{C5} \\ & -0.269 & (0.002) & \mathrm{C}\end{array}$

Rms deviation of fitted atoms =

0.059

Plane no. 4

* $\quad-0.002 \quad(0.001) \quad \mathrm{C} 1$

* $\quad 0.001(0.001) \quad \mathrm{N} 2$

* $\quad-0.001(0.001) \quad \mathrm{C} 4$

* $\quad 0.002(0.001) \quad 65$

$0.325(0.002) \quad \mathrm{C} 3$

Rns deviation of fitted atoms =

0.001

Plane no. 5

$* \quad-0.047(0.001) \quad \mathrm{C} 1$

$* \quad 0.045(0.001) \quad \mathrm{C} 3$

* $-0.073(0.001) \quad C 4$

* $0.075(0.001) \quad 05$

$-0.257(0.002) \quad \mathrm{N} 2$

Rms deviation of fitted atoms $=0.062$

Plane no. 6

* $\quad-0.075(0.001) \quad \mathrm{N} 2$

* $0.118(0.001) \quad \mathrm{C3}$

* $0.074(0.001) \quad \mathrm{C5}$

$0.093(0.002) \quad \mathrm{C} 1$

Rns deviation of fitted atoms $=0.099$ 

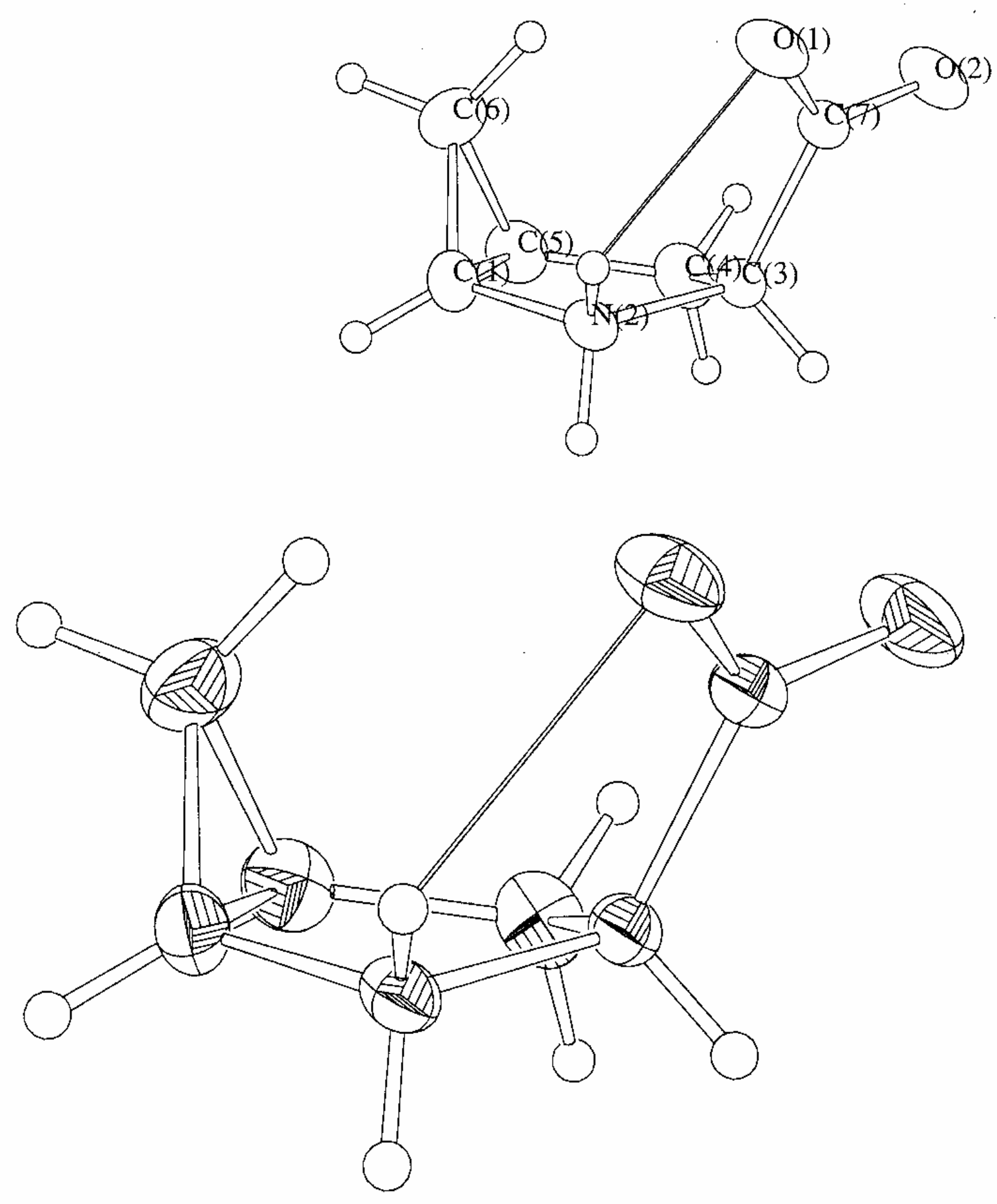

ORTEP view of the $\mathrm{C} 6 \mathrm{Hg} \mathrm{N} \mathrm{O2}$

compound with the numbering scheme adopted. Ellipsoids drawn at 408 probality level. Hydrogens represented by sphere of arbitrary size. 


\section{REFERENCES}

Ahned, F.R., Hall, S.R., Pippy, M.E. and Huber, C.P. (1973).

NRC Crystallographic Computer Programs for the IBM/360.

Accession Nos. 133-147 in J. Appl. Cryst. 6, 309-346.

Enraf-Nonius (1989). CAD-4 Software. Version 5.0. Enraf-Nonius, Delft, The Netherlands.

Flack, H.D. (1983). Acta Cryst. A39, 876-881.

Flack, H.D. and Schwarzenbach, D. (1988). Acta Cryst. A44, 499-506.

Gabe, E.J., Le Page, Y., Charland, J.-P., Lee, F.L. and White, P.S. (1989). J. Appl. Cryst. 22, 384-387.

International Tables for Crystallography (1992). Vol. C. Tables 4.2 .6 .8 and 6.1.1.4, Dordrecht: Kluwer Academic Publishers.

Joinson, C.K. (1976). ORTEPII. Report ORNL-5138. Oak Ridge Nationa1 Laboratory, Tenessee, USA.

Sheldrick, G.M. (1990). SHELXS96. Program for the Solution of Crystal Structures Univ. of Gottingen, Germany.

Sheldrick, G.M. (1996). SHELXL96. Program for the Refinement of crysta1 Structures. Univ, of Gottingen, Germany.

Spek, A.I. (1995). PLATON Molecular Geometry Program, July 1995 version. University of Utrecht, Utrecht, Holland. 